\title{
Zinc-metal-organic frameworks with tunable UV diffuse-reflectance as sunscreens
}

Jisheng Xiao ${ }^{1,2,3^{*}+}$, Haishan $\mathrm{Li}^{3 \dagger}$, Wanling Zhao ${ }^{3}$, Chengyuan Cai ${ }^{2}$, Tingting You ${ }^{2}$, Zhenyu Wang ${ }^{2}$, Mengling Wang ${ }^{4}$, Feng Zeng ${ }^{5}$, Jinmei Cheng ${ }^{2}$, Jiaxin $\mathrm{Li}^{2}$ and Xiaopin Duan ${ }^{2^{*}}$ (D)

\begin{abstract}
Background: UV exposure continues to induce many health issues, though commercial sunscreens are available. Novel UV filters with high safety and efficacy are urgently needed. Metal-organic frameworks (MOFs) could be a suitable platform for UV filter development, due to their tunable optical, electrical, and photoelectric properties by precise controlled synthesis.
\end{abstract}

Results: Herein, four zinc-based MOFs with various bandgap energies were chose to investigate their optical behaviors and evaluate their possibility as sunscreens. Zeolitic imidazolate framework-8 (ZIF-8) was found to possess the highest and widest UV reflectance, thereby protecting against sunburn and DNA damage on mouse skin and even achieving a comparable or higher anti-UV efficacy relative to the commercially available UV filters, $\mathrm{TiO}_{2}$ or $\mathrm{ZnO}$, on pig skin, a model that correlates well with human skin. Also, ZIF-8 exerted appealing characteristics for topical skin use with low radical production, low skin penetration, low toxicity, high transparency, and high stability.

Conclusion: These results confirmed ZIF-8 could potentially be a safe and effective sunscreen surrogate for human, and MOFs could be a novel source to develop more effective and safe UV filters.

Keywords: Sunscreens, Metal-organic frameworks, UV, Diffuse-reflectance, ZIF-8

\footnotetext{
*Correspondence: jsxiao2021@163.com; jsxiao@gzucm.edu.cn; xduan85@i. smu.edu.cn

${ }^{\dagger}$ Jisheng Xiao and Haishan Li contribute equally to this work

${ }^{1}$ Translational Medicine Research Center, Zhujiang Hospital, Southern

Medical University/The Second School of Clinical Medicine, Southern Medical University, Guangzhou 510515, Guangdong, China

${ }^{2}$ Cancer Research Institute, School of Basic Medical Sciences, Southern Medical University, Guangzhou 510515, China

Full list of author information is available at the end of the article
} permits use, sharing, adaptation, distribution and reproduction in any medium or format, as long as you give appropriate credit to the original author(s) and the source, provide a link to the Creative Commons licence, and indicate if changes were made. The images or other third party material in this article are included in the article's Creative Commons licence, unless indicated otherwise in a credit line to the material. If material is not included in the article's Creative Commons licence and your intended use is not permitted by statutory regulation or exceeds the permitted use, you will need to obtain permission directly from the copyright holder. To view a copy of this licence, visit http://creativecommons.org/licenses/by/4.0/. The Creative Commons Public Domain Dedication waiver (http://creativeco mmons.org/publicdomain/zero/1.0/) applies to the data made available in this article, unless otherwise stated in a credit line to the data. 


\section{Graphical Abstract}

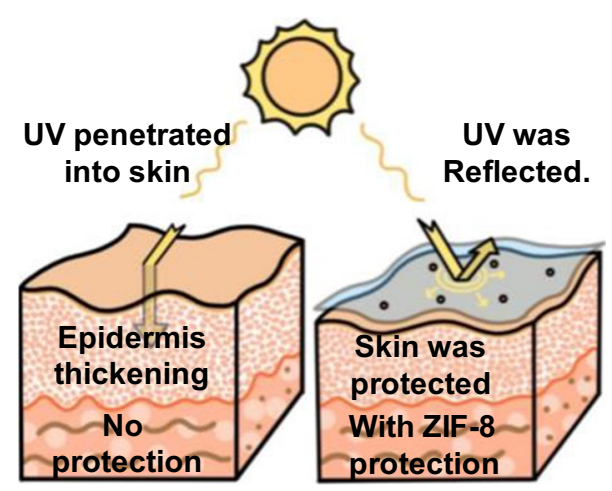

\section{Introduction}

Ultraviolet (UV) radiation produced by sun falls into three categories, including UVA at $400-320 \mathrm{~nm}$, UVB at $320-280 \mathrm{~nm}$, and UVC at $280-200 \mathrm{~nm}$. UV plays a key role for the living things and regulates many biology processes. For example, UV radiation at a suitable dose increases the production of natural endorphins and Vitamin D in the skin. However, excessive exposure of UV would lead to health risks, such as atrophy, melanin deposition, aging and skin carcinogenesis [1]. UVA is reported to induce aging, immunosuppression, and skin carcinogenesis through generation of reactive oxygen species (ROS) or upregulation of immunosuppressive cytokines. UVB potentially causes sunburn, induces DNA damage through increasing the expression of cyclobutane pyrimidine dimers (CPDs), and even leads to non-melanoma skin cancers $[2,3]$.

Commercially available organic UV filters, including benzophenones, salicylates, octinoxates, etc., have been developed for anti-UV protection with the mechanisms to absorb UV radiation and release the energy through photoreactions, fluorescence, or energy redistribution within UV filter [4]. However, these organic molecules can pass through follicles or stratum corneum, penetrate into skin cells and induce skin complications [5]. Also, these organic compounds would be further absorbed and distributed into the whole body, which potentially results in systemic toxicities (e.g. endocrine disruption) [5]. Alternatively, inorganic sunblock agents, such as titanium dioxide $\left(\mathrm{TiO}_{2}\right)$ and zinc oxide $(\mathrm{ZnO})$ nanoparticles with UV absorption and scattering characteristics have been used to protect against UV exposure and address the transdermal penetration concern of organic UV filters. However, $\mathrm{TiO}_{2}$ can induce the generation of ROS with UV irradiation, which potentially lead to damage to cells and tissues, and even the development of skin cancer, though carcinogenesis of $\mathrm{TiO}_{2}$ is still controversial
[6-8]. To address these concerns, current strategies, including decorating the nanoparticles with aluminum oxide or silica oxide or addition antioxidant molecules, have been developed to relieve the photocatalytic activity [6-8]. However, the results are not satisfied due to the degradation of antioxidants after exposure to the sun for a long time [9]. $\mathrm{ZnO}$ also is used as a surrogate for UV filter with no obvious local toxicity and no penetration of $\mathrm{ZnO}$ nanoparticles into viable epidermis [10,11]. However, $\mathrm{Zn}$ content dissociated from $\mathrm{ZnO}$ was detected in blood [10], which would potentially cause unknown biological effects, though the reported $\mathrm{Zn}$ dose in circulation is relatively low. Moreover, $\mathrm{TiO}_{2}$ and $\mathrm{ZnO}$ suspensions are prone to be opaque, which is not favored for cosmetic reasons. Therefore, novel candidates with high anti-UV efficiency, photostability, physiological stability, and transparent characteristics in suspensions are urgently needed for the development of UV filters.

Metal-organic frameworks (MOFs), the hybrid polymers formed with metal nodes and organic ligands through coordination bonds, are predominantly used in gas absorption and separation, catalysis, sensing, and biomedicine due to the properties of high stability and porosity, large surface area, and tunable functionalities. Unfortunately, MOFs have not been well exploited for sunscreen development. Semiconductor MOFs (e.g. $\mathrm{Zn}, \mathrm{Mg}, \mathrm{Cu}, \mathrm{Ni}, \mathrm{Mn}$, or Sr-based MOFs) [12] can transport photogenerated charges between metal centers or between the metal ions and linkages for long-distance by hydrogen-bonded vertical $\pi$ stacks or full $\pi-\mathrm{d}$ conjugation $[2,12-17]$. Specially, the bandgap of MOFs, which influences the maximal excitation wavelength $\left(\lambda_{\max }\right)$, can be tuned by selecting various metal nodes and organic linkers, modifying the conjugation of the linkers, and functionalizing the linkers with other groups, etc. According to photoelectric effect Eq. (1), the light will be absorbed if the wavelength is lower than $\lambda_{\max }$ and scattered or 
reflected if the wavelength is higher than $\lambda_{\max }[12,18]$ So, MOFs with tunable UV absorption and reflection characteristics due to structure variations provide us a novel channel to develop UV filters with on-demand anti-UV effects.

$$
E g=h v=h * \frac{c}{\lambda} \quad \lambda=\frac{h c}{E g}
$$

where $\mathrm{h}$ is Planck constant $\left(6.626 \times 10^{-34} \mathrm{~J} \cdot \mathrm{S}\right)$, c is light velocity $\left(3.0 \times 10^{8} \mathrm{~m} \mathrm{~s}^{-1}\right)$.

Herein, four zinc-based MOFs with different bandgap energies (Egs), including zeolitic imidazolate framework-8 (ZIF-8), $\mathrm{Zn}_{3} \mathrm{~L}_{3} \mathrm{DMF}_{2}$, MOF-5 and IRMOF-1 (isoreticular MOF-5), were selected to study their optical characteristics and find the potential sunscreens. Among them, ZIF-8 showed the widest and highest scattering of UVA and UVB, followed by IRMOF-1, MOF-5, $\mathrm{Zn}_{3} \mathrm{~L}_{3} \mathrm{DMF}_{2}, \mathrm{TiO}_{2}$ and $\mathrm{ZnO}$ (Fig. $1 \mathrm{C}$, D, Additional file 1: Fig. S2), thus ZIF-8 was selected as the final model MOFs to assess its potential as UV filters. ZIF-8 was more transparent compared to $\mathrm{ZnO}$ and $\mathrm{TiO}_{2}$ with high physiological stability, low skin toxicity, and weak ROS production (Figs. 1B, E, F, 6A, B). On the mouse skin, ZIF-8 successfully inhibited epidermal hyperplasia and collagen degradation caused by UV exposure. On the Ba-Ma miniature pig skin, a model that correlates well with human skin, ZIF-8 achieved better effects to inhibit epidermal hyperplasia and DNA damage than $\mathrm{ZnO}$, and comparable effect relative to $\mathrm{TiO}_{2}$. Furthermore, negligible ZIF-8 was found to penetrate mouse and pig skin, combined with low ROS generation, making it safer for clinical use. All these results confirmed ZIF-8 could potentially be used as a novel sunscreen surrogate for human. As we are investigating a new use of metal organic frameworks and how they perform on UV absorbance/reflectance with structure variations, we believe that our results are relevant to wide research areas including aesthetic medicine, pharmacy, and materials science.

\section{Results and discussion}

\section{Physical and chemical characterizations of Zn-based MOFs}

MOFs were successfully synthesized and the structures of MOFs, $\mathrm{TiO}_{2}$ and $\mathrm{ZnO}$ were confirmed in the experiment section (Additional file 1: Figs. S1-S16). TEM revealed sizes of $102.1 \pm 18.9 \mathrm{~nm}$ and $114.8 \pm 53.2 \mathrm{~nm}$ for $\mathrm{TiO}_{2}$ and $\mathrm{ZnO}$, respectively, whereas ZIF-8 showed a similar size with $82.3 \pm 24.5 \mathrm{~nm}$ in diameter (Fig. 1A, Additional file 1: Fig. S1), confirming $\mathrm{TiO}_{2}, \mathrm{ZnO}$ and ZIF-8 are in nanoparticulate form. The sizes for MOF-5, IRMOF-1, and $\mathrm{Zn}_{3} \mathrm{~L}_{3} \mathrm{DMF}_{2}$ were $310.6 \pm 142.4 \mathrm{~nm}, 47.1 \pm 13.6 \mathrm{~nm}$, and $256.0 \pm 91.3 \mathrm{~nm}$, respectively (Additional file 1:
Fig. S13A-F). The zeta potentials also were measured, showing $31.7 \pm 0.6 \mathrm{mV}, 16.4 \pm 0.7 \mathrm{mV}, 29.5 \pm 0.8 \mathrm{mV}$, $-9.9 \pm 1.5 \mathrm{mV},-7.0 \pm 0.6 \mathrm{mV}$, and $-5.6 \pm 0.6 \mathrm{mV}$ for $\mathrm{TiO}_{2}$, ZnO, ZIF-8, MOF-5, IRMOF-1, and $\mathrm{Zn}_{3} \mathrm{~L}_{3} \mathrm{DMF}_{2}$, respectively (Additional file 1: Fig. S13G). The previously reported bandgaps for MOFs, $\mathrm{TiO}_{2}$, and $\mathrm{ZnO}$ are $\mathrm{ZIF}-8$ $(5.5 \mathrm{eV})>$ IRMOF-1 $(3.6 \mathrm{eV})>\mathrm{MOF}-5(3.4 \mathrm{eV})>\mathrm{TiO}_{2}$ $(3.2 \mathrm{eV})=\mathrm{ZnO}(3.2 \mathrm{eV})>\mathrm{Zn}_{3} \mathrm{~L}_{3} \mathrm{DMF}_{2}(3.1 \mathrm{eV})[12,19$, 20], and the calculated $\lambda_{\max }$ order should be ZIF-8 $<$ IRM OF- $1<$ MOF $-5<\mathrm{TiO}_{2}=\mathrm{ZnO}<\mathrm{Zn}_{3} \mathrm{~L}_{3} \mathrm{DMF}_{2}$ according to photoelectric effect Eq. (1). However, the diffuse-reflectance results showed ZIF-8 exerted lowest $\lambda_{\max }(236 \mathrm{~nm})$, followed by IRMOF-1 ( $\left.\lambda_{\max }: 290 \mathrm{~nm}\right)$, MOF-5 $\left(\lambda_{\max }\right.$ : $294 \mathrm{~nm}), \mathrm{TiO}_{2}\left(\lambda_{\max }: 340 \mathrm{~nm}\right), \mathrm{Zn}_{3} \mathrm{~L}_{3} \mathrm{DMF}_{2}\left(\lambda_{\max }: 366 \mathrm{~nm}\right)$ and $\mathrm{ZnO}\left(\lambda_{\max }: 370 \mathrm{~nm}\right)$ (Fig. $1 \mathrm{C}, \mathrm{D}$, Additional file 1: Fig. S2), indicating the acquired $\lambda_{\max }$ order from experiment did not correlate well with the calculated one, which could be due to red and blue shifts caused by the quantum size effect and dielectric confinement effect [21]. As shown in the Eq. (2) for the lowest exciton energy, $\pi^{2} / \widehat{R}^{2}$ could cause a blue shift with the decline of particle size, whereas $A_{1} / R$ and $A_{0}$ would result in a red shift with the decreasing of particle size and rising of dielectric-constant ratio $\epsilon_{1} / \epsilon_{2}[21]$.

$$
\begin{aligned}
E g & =\frac{\pi^{2}}{\hat{R}^{2}}+\frac{-8 \pi I_{2}+4 I_{3}-2 \pi^{2} \alpha_{0}}{\pi^{2}} \frac{1}{\hat{R}}-\bar{\alpha}^{2}+\varphi(\hat{R}) \\
& =\frac{\pi^{2}}{\hat{R}^{2}}+\frac{A_{1}}{\hat{R}}+A_{0}+\varphi(\hat{R})
\end{aligned}
$$

where $\hat{R}=R / a_{B}{ }^{\prime \prime}$ ( $R$ is radius of nanoparticle, $a_{B}{ }^{*}$ is the exciton Bohr radius in bulk material; The information of the other quantities in this equation could be found in Additional file 1: Eqs. S2.1-2.7 [21].

ZIF-8 showed the lowest $\lambda_{\max }(236 \mathrm{~nm})$ and highest bandgap, meaning ZIF-8 needs more energy to generate electronic transition from full band to conducting band, which resulted in a UV absorption at low wavelength range and exerted a UV reflection at high wavelength range. The wide reflection of UVA, UVB and even some UVC could potentially endow ZIF-8 with a high anti-UV efficacy. So ZIF-8 was selected as the model MOFs for further study.

A widely used in vitro sun protection factor (SPF) assay with timesaving and no human subject involvement properties was performed to compare the photoprotective efficacy of $\mathrm{ZIF}-8, \mathrm{TiO}_{2}$ and $\mathrm{ZnO}[22,23]$. ZIF-8 revealed an SPF value of 15.6, while which were 15.3 and 9.6 for $\mathrm{TiO}_{2}$ and $\mathrm{ZnO}$, respectively, suggesting ZIF-8 could potentially provide a comparable or even higher UV protection effect relative to $\mathrm{TiO}_{2}$ and $\mathrm{ZnO}$, respectively (Additional file 1: Fig. S16). Additionally, the SPF values of $\mathrm{TiO}_{2}$ and $\mathrm{ZnO}$ correlated well with that 

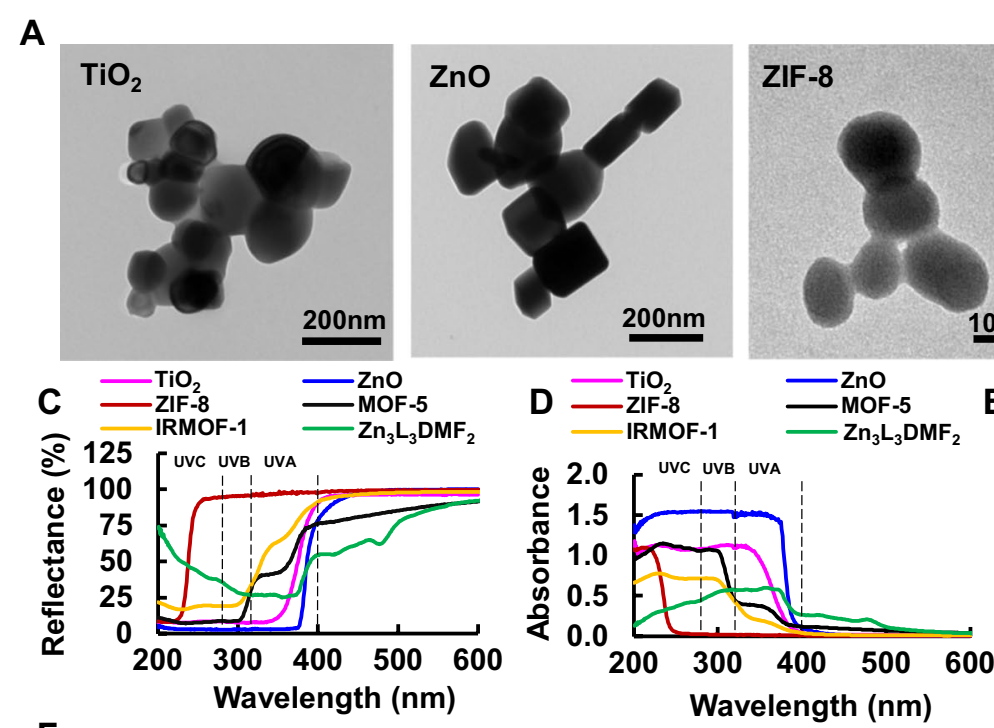

B
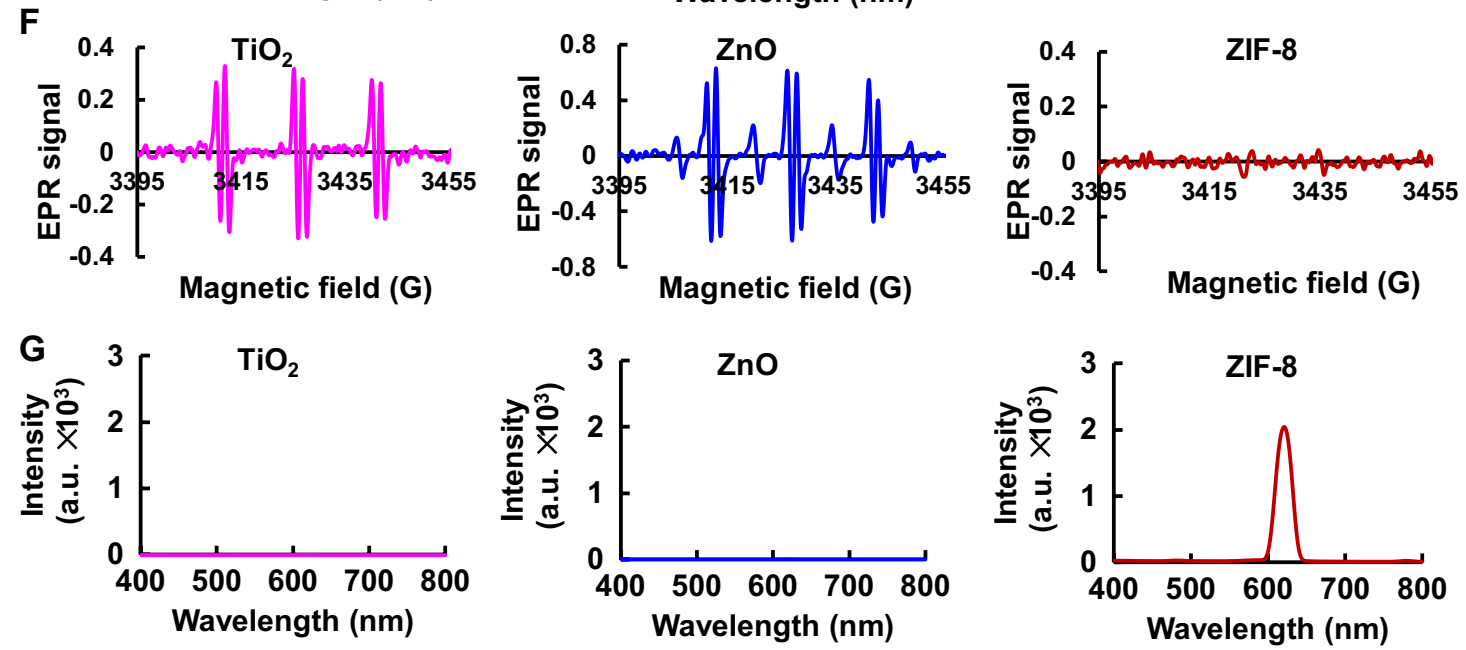

H
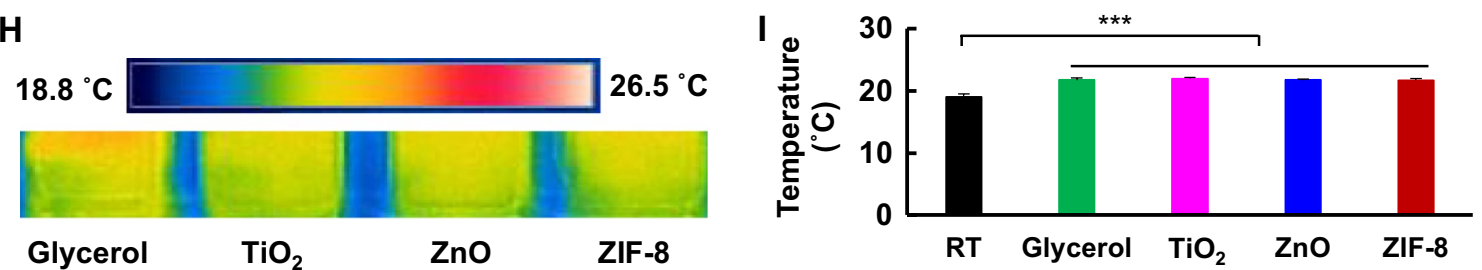

Fig. 1 Physical and chemical characterizations of zinc-based MOFs. A TEM images of $\mathrm{TiO}_{2}, \mathrm{ZnO}$ and ZIF-8. B Digital photographs of TiO 2 , ZnO and ZIF-8. ZIF-8 suspension was more transparent relative to $\mathrm{TiO}_{2}$ and $\mathrm{ZnO}$. C Diffuse reflection spectra and $\mathbf{D}$ calculated UV-Vis absorbance spectra for $\mathrm{TiO}_{2}, \mathrm{ZnO}$ and zinc-based MOFs. ZIF-8 showed the widest and highest UVA and UVB scattering with lowest $\lambda_{\max }$. $\mathrm{ZIF-8}$ degradation in artificial sweat $\left(\mathrm{pH} 6.5,32^{\circ} \mathrm{C}\right)$. F EPR spectra of POBN-OH spin abduct signal produced by $\mathrm{TiO}_{2}, \mathrm{ZnO}$ and $\mathrm{ZIF}-8$ suspensions $\left(800 \mu \mathrm{g} \mathrm{mL}{ }^{-1}\right.$ in ethanol). $\mathrm{ZIF-8}$ induced less EPR signal compared to $\mathrm{TiO}_{2}$ after UV exposure. G Fluorescence spectra of $\mathrm{TiO}_{2}, \mathrm{ZnO}$ and $\mathrm{ZIF}-8$ after excitation with UV light (308 nm). ZIF-8 showed an emission at $621 \mathrm{~nm}$. H Thermographs and I quantitative analysis of glycerol, $\mathrm{TiO}_{2}, \mathrm{ZnO}$ and $\mathrm{ZIF}-8$ after UV exposure for $2 \mathrm{~h}$. (RT: room temperature) $2-3^{\circ} \mathrm{C}$ temperature increases were observed for all four groups compared to room temperature

reported in the literatures, with 11.68 for $\mathrm{TiO}_{2}(15 \%)$ and 8.74 for $\mathrm{ZnO}(15 \%)[24,25]$.

The digital photographs were taken under normal room light for the suspensions of $\mathrm{TiO}_{2}$ (15 wt\%), $\mathrm{ZnO}$ (15 wt.\%) and ZIF-8 (15 wt\%) in glycerol. ZIF-8 yielded a much more transparent suspension in glycerol relative to that of $\mathrm{TiO}_{2}$ and $\mathrm{ZnO}$, which is a competitive advantage from aesthetic considerations (Fig. 1B). ZIF-8 showed a low degradation in artificial sweat (36.2 $\pm 0.5 \%$ of degradation within $24 \mathrm{~h}$ ) (Fig. 1E), which could potentially lower 
skin penetration and result in less time for ZIF-8 clearance. Nanoparticles would induce conduction band electron $\left(\mathrm{e}^{-}\right)$and valence band hole $\left(\mathrm{h}^{+}\right)$after UV radiation, which could further react with surrounding medium and produce free radicals of $\mathrm{H}^{+}, \mathrm{H}_{2} \mathrm{O}_{2}, \mathrm{OH}$ or $\mathrm{HO}_{2}$. Therefore, we studied the free radical formation of $\mathrm{ZIF}-8, \mathrm{TiO}_{2}$, $\mathrm{ZnO}$, MOF-5, IRMOF-1 and $\mathrm{Zn}_{3} \mathrm{~L}_{3} \mathrm{DMF}_{2}$ using electron paramagnetic resonance (EPR) method. Interestingly, $\mathrm{ZnO}$ produced most free radical of $\cdot \mathrm{OH}\left(1.3 \times 10^{12}\right.$ spins $\left./ \mathrm{mm}^{3}\right)$, followed by $\mathrm{TiO}_{2}\left(5.9 \times 10^{11} \mathrm{spins} / \mathrm{mm}^{3}\right)$, MOF-5 $\left(4.1 \times 10^{11}\right.$ spins $\left./ \mathrm{mm}^{3}\right), \mathrm{Zn}_{3} \mathrm{~L}_{3} \mathrm{DMF}_{2}\left(2.1 \times 10^{11}\right.$ spins $\left./ \mathrm{mm}^{3}\right)$, IRMOF-1 $\left(6.2 \times 10^{10} \mathrm{spins} / \mathrm{mm}^{3}\right)$ and ZIF-8 $\left(2.3 \times 10^{10}\right.$ spins $\left./ \mathrm{mm}^{3}\right)$ (Fig. 1F, Additional file 1: Fig. S15), suggesting ZIF-8 induced the least EPR signal compared to $\mathrm{TiO}_{2}, \mathrm{ZnO}$, and the other $\mathrm{Zn}$-based MOFs and exhibited weakest photocatalytic activity to generate hydroxyl radical, a hazard to human skin if topically applied. We also measured the temperature change and fluorescence production after the samples were exposed to UV, as the absorbed UV energy would be transferred into heat, fluorescence, or phosphorescence. Only $2-3{ }^{\circ} \mathrm{C}$ temperature increases were observed for all four groups compared to room temperature (RT) (Fig. 1H, I), suggesting that ZIF8, $\mathrm{TiO}_{2}$ and $\mathrm{ZnO}$ would not do a second burn harm to the skin. Interestingly, a fluorescence at $621 \mathrm{~nm}$ was detected for ZIF-8 after UV exposure, indicating that the absorbed UV energy could partially be released as fluorescence for ZIF-8 (Fig. 1G). All these results above confirmed the UV reflection and absorption of MOFs could be tuned by changing the ligands. The selected MOFs, ZIF-8, showed appealing characteristics compared to commercial UV filters with wider and higher UV reflection, lower ROS production, and more transparent appearance.

\section{In vitro cytotoxicity}

The toxicity of ZIF-8 to human immortalized epidermal keratinocytes (HaCaTs) and human epithelial keratinocytes (HEKas) cells was assessed using MTT (3-(4,5-dimethylthiazol-2-yl)-2,5-diphenyltetrazolium bromide) assay, a widely used tool to estimate the metabolic activity of living cells, where formazan with intense purple-blue color was formed from the lightly colored tetrazolium salt due to enzymatic reduction [26]. ZIF-8 showed much lower cytotoxicity compared to $\mathrm{ZnO}$ on both cell lines. The $\mathrm{HaCaT}$ survival rate was as high as $91.3 \pm 1.6 \%$ for ZIF-8 at $50 \mu \mathrm{g} \mathrm{mL} \mathrm{m}^{-1}$, whereas which was only $11.0 \pm 3.9 \%$ for $\mathrm{ZnO}$ at the same concentration. The survival rate of HEKas was decreased from
$94.5 \pm 2.8 \%$ to $79.0 \pm 2.8 \%$ and $77.5 \pm 0.3 \%$ for ZIF-8 at 10,25 , and $50 \mu \mathrm{g} \mathrm{mL}^{-1}$, respectively. On the contrary, the viability rate of cells treated with $\mathrm{ZnO}$ was $81.9 \pm 2.2 \%$, $36.8 \pm 3.0 \%$, and $10.8 \pm 0.8 \%$, respectively. No obvious cytotoxicity was observed for $\mathrm{TiO}_{2}$ at these concentrations (Fig. 2A). The cell apoptosis induced by these three nanoparticles also was evaluated by observing the cell and nucleus morphologies or by calculating cell apoptosis rates using flow cytometry. Obvious cell apoptosis with cell shrinkages and chromatin condensation was observed for both HaCaTs and HEKas after $\mathrm{ZnO}$ treatment at $60 \mu \mathrm{g} \mathrm{mL}^{-1}$ for $12 \mathrm{~h}$ or $8 \mathrm{~h}$, respectively (Fig. 2B, C). Furthermore, the flow cytometry analysis showed that $\mathrm{HaCaT}$ apoptosis rates were $2.36 \%, 21.78 \%$, and $5.73 \%$ after exposure with $\mathrm{TiO}_{2}, \mathrm{ZnO}$ and $\mathrm{ZIF}-8$, respectively, whereas which were $4.66 \%, 42.20 \%$, and $15.45 \%$ for HEKas (Fig. 2D), indicating that ZIF-8 caused much less cell apoptosis and could be more biocompatible relative to $\mathrm{ZnO}$. However, it is still controversial for the cell toxicity of $\mathrm{ZnO}$, because these assays do not take skin delivery into consideration [27]. Also, toxicity depends on exposure and toxic nature, $\mathrm{ZnO}$ toxicity could potentially not mean that much with absence of cellular exposure [10].

\section{Protection against DNA damage after UV exposure}

UVB is reported to induce oxidative DNA damage through the generation of free radicals and ROS $[2,28]$. In order to test the protective effect of ZIF-8 against UVB, comet assay was performed, and DNA damage was quantified. Without protection, $71.5 \pm 9.3 \%$ of $\mathrm{HaCaTs}$ possessed DNA tails (single-strand or double-strand DNA breaks), whereas which was significantly reduced to $51.7 \pm 3.5 \%$ with ZIF- 8 protection and $38.5 \pm 9.5 \%$ with $\mathrm{TiO}_{2}$ protection. HEKas showed a similar result, with $74.9 \pm 6.0 \%$ for no protection group but $52.7 \pm 3.6 \%$ and $29.4 \pm 2.1 \%$ for ZIF-8 and $\mathrm{TiO}_{2}$ groups, respectively (Fig. 3A-C). These results confirmed ZIF-8 could efficiently prevent DNA breaks in skin cells after UV exposure, possibly due to its high UV reflection capability. $\mathrm{TiO}_{2}$ also exerted high DNA protection effects, potentially caused by its high UV absorption [29]. ZnO did not show protective effect against DNA fragmentation, which may be due to UV exposure accelerated the entrance of $\mathrm{ZnO}$ to skin cells, resulted in more ROS production due to the increased $\mathrm{ZnO}$ level and finally DNA damage [28].

The UV shielding capability of $\mathrm{ZIF}-8, \mathrm{TiO}_{2}$, and $\mathrm{ZnO}$ also was assessed using $\mathrm{MTT}$ assay. $\mathrm{TiO}_{2}$ significantly increased $\mathrm{HaCaT}$ viabilities to $60.9 \pm 8.2 \%$ at

(See figure on next page.)

Fig. 2 Toxicity on HaCaTs and HEKas. A Cytotoxicity of $\mathrm{TiO}_{2}, \mathrm{ZnO}$ and $\mathrm{ZIF}-8$ at various concentrations toward HaCaTs and HEKas using MTT assay. B Digital images of $\mathrm{HaCaTs}$ and $\mathrm{HEKas}$ after treatment with $\mathrm{TiO}_{2}, \mathrm{ZnO}$ or $\mathrm{ZIF}-8 . \mathbf{C}$ Nucleus images with DAPI staining after cells were treated with $\mathrm{TiO}_{2}$, $\mathrm{ZnO}$ or ZIF-8. Obvious chromatin condensation was observed for ZnO-treated cells. D Flow cytometry analysis of cell apoptosis induced by $\mathrm{TiO}_{2}$ $\mathrm{ZnO}$ and $\mathrm{ZIF}-8$ 

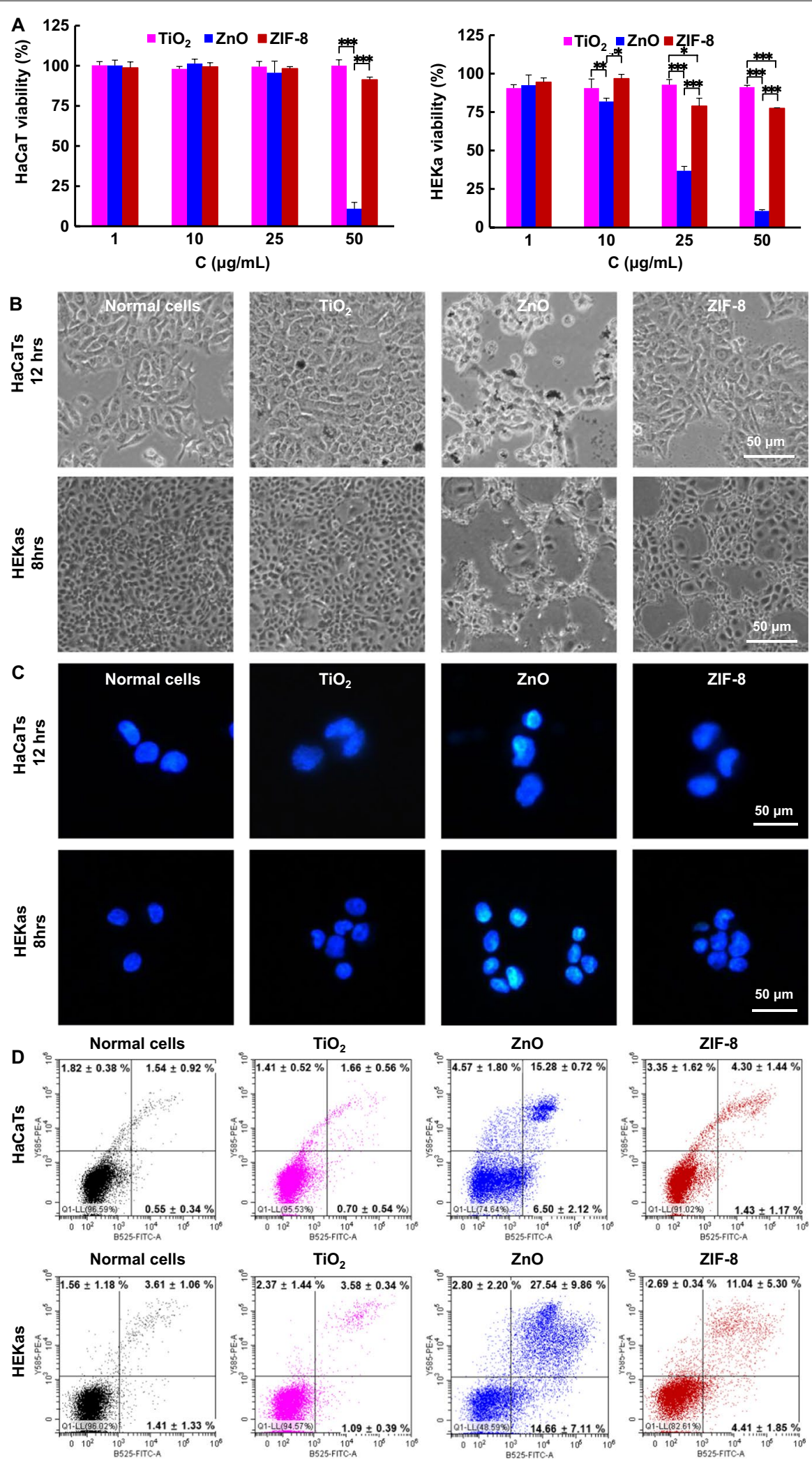

Fig. 2 (See legend on previous page.) 


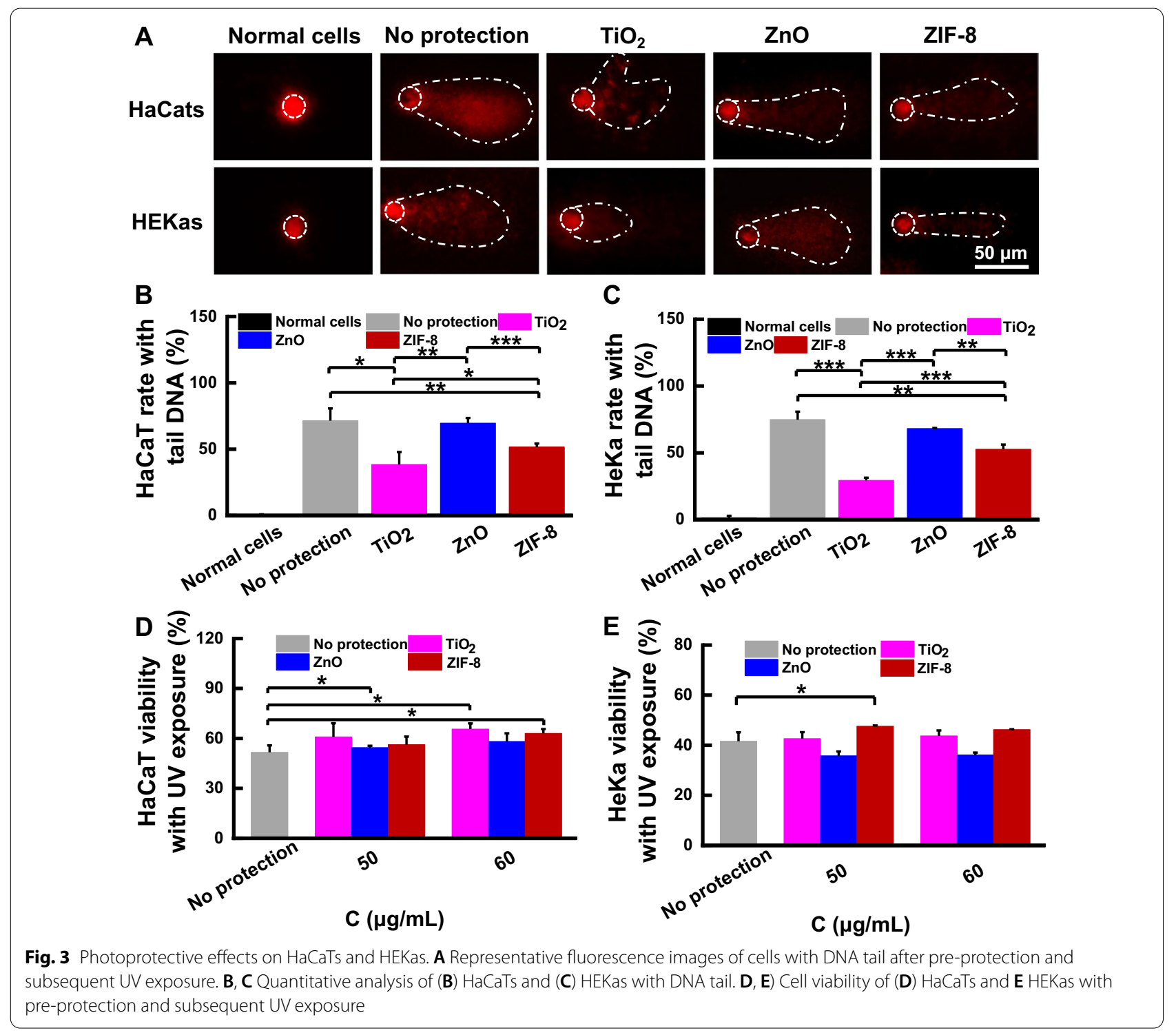

$50 \mu \mathrm{g} \mathrm{mL}^{-1}$ and $65.6 \pm 3.4 \%$ at $60 \mu \mathrm{g} \mathrm{mL}^{-1}$, compared to cells without protection $(51.6 \pm 4.2 \%)$. ZIF-8 also exerted a protective effect for $\mathrm{HaCats}$, with $63.0 \pm 2.7 \%$ cell viability at $60 \mu \mathrm{g} \mathrm{mL} \mathrm{m}^{-1}$. Unfortunately, $\mathrm{ZnO}$ did not protect $\mathrm{HaCaTs}$ against UV irradiation, as shown by negligible changes on cell viabilities. For HEKas, only ZIF-8 at $50 \mu \mathrm{g} \mathrm{mL} \mathrm{m}^{-1}$ revealed an obviously higher cell viability with $47.6 \pm 0.3 \%$, compared to non-protection group $\left(41.6 \pm 3.6 \%\right.$ ) (Fig. $3 \mathrm{D}, \mathrm{E}$ ). $\mathrm{ZIF}-8, \mathrm{TiO}_{2}$ and $\mathrm{ZnO}$ were not toxic in this test, because the nanoparticles were washed away using PBS and the cells were cultured in fresh medium without nanoparticles after UV exposure. These results confirmed that both $\mathrm{TiO}_{2}$ and ZIF-8, but not $\mathrm{ZnO}$, could efficiently protect cells against UV exposure.

\section{Protection against ROS generations in skin cells}

ROS levels in HaCaTs and HEKas were measured using confocal fluorescent microscopy and flow cytometry after UVB or UVA exposures. After UVB irradiation, $\mathrm{HaCaTs}$ and HEKas with ZIF-8 pretreatment showed no obvious or less increase of ROS relative to that of the cells without protection or with the protections of $\mathrm{TiO}_{2}, \mathrm{ZnO}$, MOF-5, IRMOF-1 or $\mathrm{Zn}_{3} \mathrm{~L}_{3} \mathrm{DMF}_{2}$ (Additional file 1: Figs. S19, 20). After UVA exposure, both cells revealed similar results, with few or less ROS generations in ZIF-8 group, whereas which were elevated in the groups of No protection, $\mathrm{TiO}_{2}, \mathrm{ZnO}$, MOF-5, IRMOF-1 and $\mathrm{Zn}_{3} \mathrm{~L}_{3} \mathrm{DMF}_{2}$ (Additional file 1: Figs. S21, 22). All these results confirmed ZIF-8 could effectively reduce ROS productions in skin cells with UVA or UVB exposures. 


\section{Protective effects on mouse skin}

The anti-UV effects of ZIF-8 was assessed on the dorsal skin of BALB/c mice, which was divided into five parts $(1 \mathrm{~cm} \times 1 \mathrm{~cm}$ for each part), preincubated with either glycerol, $\mathrm{ZnO}, \mathrm{TiO}_{2}$, or ZIF-8 at an optimized dose of $15 \%$ for $15 \mathrm{~min}$, and then exposed to UVB (280-320 nm) at an optimized UV dose of $206 \mathrm{~mJ} \mathrm{~m}^{-2}$. The skin with no protection was used as control (Additional file 1: Figs. S23, 24). After three days, the skin with treatments of $\mathrm{ZIF}-8, \mathrm{ZnO}$ and $\mathrm{TiO}_{2}$ showed much less ulceration, edema or erythema compared to that of glycerol or no protection groups (Fig. 4A, Additional file 1: Fig. S25), suggesting $\mathrm{ZIF}-8, \mathrm{ZnO}$ and $\mathrm{TiO}_{2}$ are all protective against macroscopic skin damages from UVB. Also, the skin histological assay by H\&E staining revealed that the epidermal thickness was significantly increased after UV exposure from $20.1 \pm 2.6 \mu \mathrm{m}$ for normal skin to $56.6 \pm 4.1 \mu \mathrm{m}$ and $45.5 \pm 3.2 \mu \mathrm{m}$ for no protection and glycerol groups, respectively. However, the epidermal thickness increase was significantly inhibited by $\mathrm{TiO}_{2}$, $\mathrm{ZnO}$ and $\mathrm{ZIF}-8$ treatments, with an epidermal thickness of $26.5 \pm 4.6 \mu \mathrm{m}, 27.9 \pm 2.1 \mu \mathrm{m}$, and $30.8 \pm 4.1 \mu \mathrm{m}$, respectively. No obvious difference for epidermal thickness was observed for these three groups (Fig. 4B, D), confirming ZIF-8 achieved comparable anti-epidermal hyperplasia effects to $\mathrm{TiO}_{2}$ and $\mathrm{ZnO}$ on mouse skin, which would contribute to a smoother skin appearance.

UVB irradiation induces the formation of cyclobutane pyrimidine dimers (CPDs), causes DNA lesions, blocks normal DNA replication if DNA damage is not repaired and leads to mutagenesis and even carcinogenesis [30]. So CPDs formed in the skin after UV irradiation was stained using immunohistochemistry (IHC). Obvious CPDs were observed for the skin without protection $\left(30.3 \pm 0.5 \mathrm{CPD}^{+}\right.$cells per $\left.\mathrm{mm}^{2}\right)$ and glycerol pretreatment $\left(30.4 \pm 4.1 \mathrm{CPD}^{+}\right.$cells per $\left.\mathrm{mm}^{2}\right)$, but which was obviously reduced for the skins with $\mathrm{ZIF}-8, \mathrm{ZnO}$ or $\mathrm{TiO}_{2}$ protections $\left(10.6 \pm 2.5,15.7 \pm 2.1\right.$, or $8.6 \pm 0.5 \mathrm{CPD}^{+}$cells per $\mathrm{mm}^{2}$, respectively). ZIF-8 even achieved a significant reduction of $\mathrm{CPD}$ compared to $\mathrm{ZnO}$, confirming $\mathrm{ZIF}-8$ could protect skin against UV-caused DNA damage on mouse skin (Fig. 4C, E). The lowered CPD formation

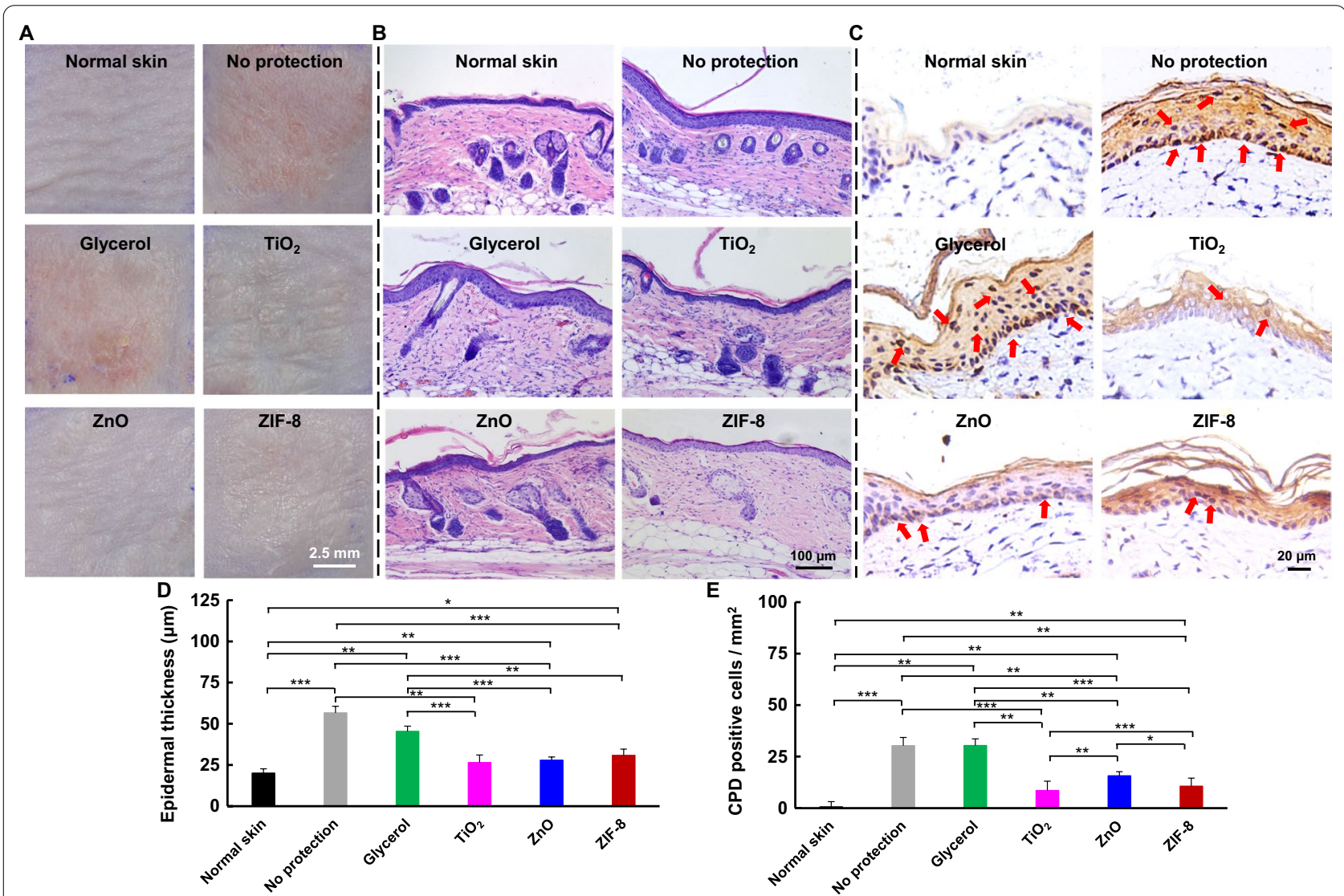

Fig. 4 Photoprotective effects on mouse skin. A Representative digital graphs of mouse dorsal skin three days after pre-protection and subsequent UV exposure. ZIF-8 group showed less erythema compared to no protection or glycerol groups. B Microscope photographs of skin with H\&E staining. C Microscope photographs of skin with CPD immunohistochemistry. D, E Quantitative analysis of (D) epidermal thickness and E CPD positive cells in the skin after pre-protection and subsequent UV exposure. ZIF-8 inhibited epidermal hyperplasia and CPD formation 
could be due to the reduced ROS formation for the skin with ZIF-8 shielding. After UVB irradiation, the ROS level was $(2.4 \pm 0.3) \times 10^{5}$ for the skin with ZIF-8 protection, which was significantly lower relative to that of $\mathrm{TiO}_{2}$ $\left((3.4 \pm 0.6) \times 10^{5}\right)$ and $\mathrm{ZnO}\left((4.4 \pm 1.1) \times 10^{5}\right)$ groups, respectively, and even comparable to that of normal skin $\left((2.5 \pm 0.2) \times 10^{5}\right)$ without UVB exposure, suggesting ZIF- 8 could effectively protect the skin against ROS generation caused by UVB irradiation (Additional file 1: Fig. S26).

Collagen is an essential component to maintain skin structure, and the degradation of which after UV radiation would cause wrinkling and laxity [31]. Thus, we performed Masson's trichrome staining for paraffin sections of the skin. Compared to normal skin, a reduced collagen density and irregularly distributed collagen fiber were observed after UV exposure for no protection and glycerol groups, but not for $\mathrm{ZIF}-8, \mathrm{TiO}_{2}$ and $\mathrm{ZnO}$ groups, confirming ZIF-8 exerted a similar protective effect to $\mathrm{TiO}_{2}$ and $\mathrm{ZnO}$ against collagen degradation induced by UV irradiation (Additional file 1: Fig. S27A). The collagen protective effect of ZIF-8 would be beneficial to the maintenance of a smooth skin after UV exposure.

UVB exposure is also reported to cause pro-inflammatory responses with elevated levels of pro-inflammatory cytokines (such as IL-1 $\beta$, TNF- $\alpha$ and IL- 6 ) and lead to inflammatory disequilibrium in the skin [32-35]. We found that IL-1 $\beta$ expression in the skin was increased for no protection and glycerol groups after UV exposure, while which was not observed for $\mathrm{ZIF}-8, \mathrm{TiO}_{2}$ and $\mathrm{ZnO}$ groups, suggesting ZIF- 8 could inhibit IL- $1 \beta$ expression, thereby mitigating pro-inflammatory responses (Additional file 1: Fig. S27B). Overexpression of IL-1 $\beta$ would result in overproduction of MMP-2, MMP-9 and MMP12 , which would further lead to the degradation of elastin and collagens I, II and III [32, 36-38]. The inhibition of ZIF-8 on IL-1 $\beta$ overexpression would contribute to the maintenance of collagen morphology and well collagen distribution in the skin, endowing a smooth, full and firm skin appearance.

\section{Protective effects on pig skin}

In order to evaluate the clinical translational potential of ZIF-8 as sun-screening agent, we further investigated the protective effect of ZIF-8 on Ba-Ma miniature pig, which shows similar skin histology compared to that of human in terms of horny layer thickness, epidermal and dermal thicknesses, epidermis/dermis ratio, and collagen physicochemical properties [39]. Also, Ba-Ma miniature pig exhibits some special characteristics, including heterogeneity of basal cells, granules of mast cells, serrated pattern for epidermal-dermal interface, and developed vascular system, which are found only on the skin of humans, nonhuman primates, and pigs [39]. The dorsal skin of Ba-Ma miniature pig was demarcated into squares $(1 \mathrm{~cm} \times 1 \mathrm{~cm})$, randomly pretreated with glycerol, $\mathrm{TiO}_{2}, \mathrm{ZnO}$, or ZIF- 8 for $15 \mathrm{~min}$, and exposed to UVB radiation at the optimized dose $\left(544 \mathrm{~mJ} \mathrm{~cm} \mathrm{~cm}^{-2}\right)$ with an optimized ZIF-8 dose of $15 \%$ (Additional file 1: Figs. S28, 29). After UV exposure, the skin with protections of $\mathrm{ZIF}-8, \mathrm{TiO}_{2}$, or $\mathrm{ZnO}$ exhibited much less erythema compared to that of the skin without protection or with protection of glycerol (Fig. 5A, Additional file 1: Fig. S30). Also, the epidermal layer thickness was increased from $33.5 \pm 0.9 \mu \mathrm{m}$ for normal skin to $79.9 \pm 6.7 \mu \mathrm{m}$ or $74.1 \pm 3.6 \mu \mathrm{m}$ for no protection or glycerol groups. However, the epidermal layer thickness was significantly lowered by $\mathrm{TiO}_{2}(43.1 \pm 0.9 \mu \mathrm{m})$, $\mathrm{ZnO}(53.7 \pm 6.6 \mu \mathrm{m})$, or ZIF-8 $(44.4 \pm 2.5 \mu \mathrm{m})$ groups, suggesting all of them could inhibit the epidermal hyperplasia after UV exposure. Interestingly, the epidermal thickness of ZIF-8 group was similar to that of $\mathrm{TiO}_{2}$, which was much thinner than that of $\mathrm{ZnO}$ group, confirming ZIF-8 achieved comparable anti-epidermal hyperplasia effects to $\mathrm{TiO}_{2}$ and even better effects than $\mathrm{ZnO}$ (Fig. 5B, D).

UV exposure would induce skin DNA damage with the formation of DNA double-strand breaks (DSB), which further induces the phosphorylation of histone $\mathrm{H}_{2} \mathrm{AX}$ on serine 139 [40]. Thus, $\gamma-\mathrm{H}_{2} \mathrm{AX}$ formation is considered as a DSB-response marker and was assessed using immunofluorescence staining. UV irradiation induced remarkable $\gamma-\mathrm{H}_{2} \mathrm{AX}$ on no protection skin and glycerol pretreated skin, with $48.4 \pm 7.3$ and $37.8 \pm 7.7 \gamma-\mathrm{H}_{2} \mathrm{AX}$ positive $\left(\gamma-\mathrm{H}_{2} \mathrm{AX}^{+}\right)$cells per $\mathrm{mm}^{2}$, respectively. However, after pretreatment with $\mathrm{TiO}_{2}, \mathrm{ZnO}$ or $\mathrm{ZIF}-8, \gamma-\mathrm{H}_{2} \mathrm{AX}{ }^{+}$ cells were significantly reduced to $20.6 \pm 1.2,28.5 \pm 3.2$, and $22.6 \pm 3.2$ per $\mathrm{mm}^{2}$ (Fig. $5 \mathrm{C}, \mathrm{E}$ ), suggesting ZIF-8 achieved comparable effects to $\mathrm{TiO}_{2}$ and $\mathrm{ZnO}$ on inhibiting UV-induced DNA damage.

Porcine skin is confirmed to be a suitable model for sunscreen protection efficacy assessment because the universal sun protection factor obtained using porcine skin correlates well with that on human skin (correlation factor $\mathrm{R}^{2}=0.98$ ) [41]. The comparable or even higher anti-UV efficacy of ZIF-8 relative to $\mathrm{TiO}_{2}$ or $\mathrm{ZnO}$ on pig skin suggests that ZIF- 8 could be a potential effective sunscreen surrogate for human.

\section{Long-term in vivo toxicity}

We studied the long-term toxicity by applying either glycerol, $\mathrm{TiO}_{2}, \mathrm{ZnO}$ or ZIF-8 to mouse dorsal skin once every other day for a total of 6 applications. The skin showed no obvious signs of acute histology toxicity or long-term inflammation for all four groups. The epidermis structures, including corneum structure, epidermis 

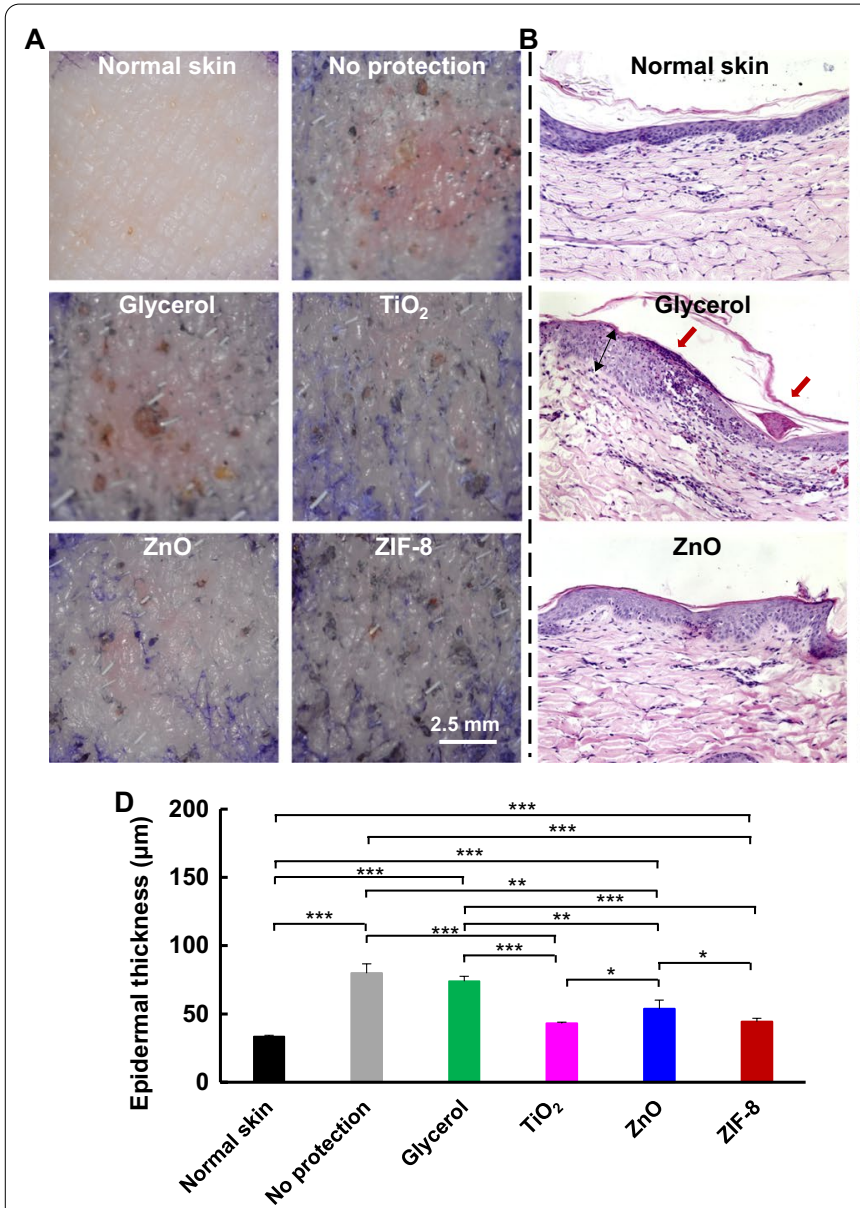
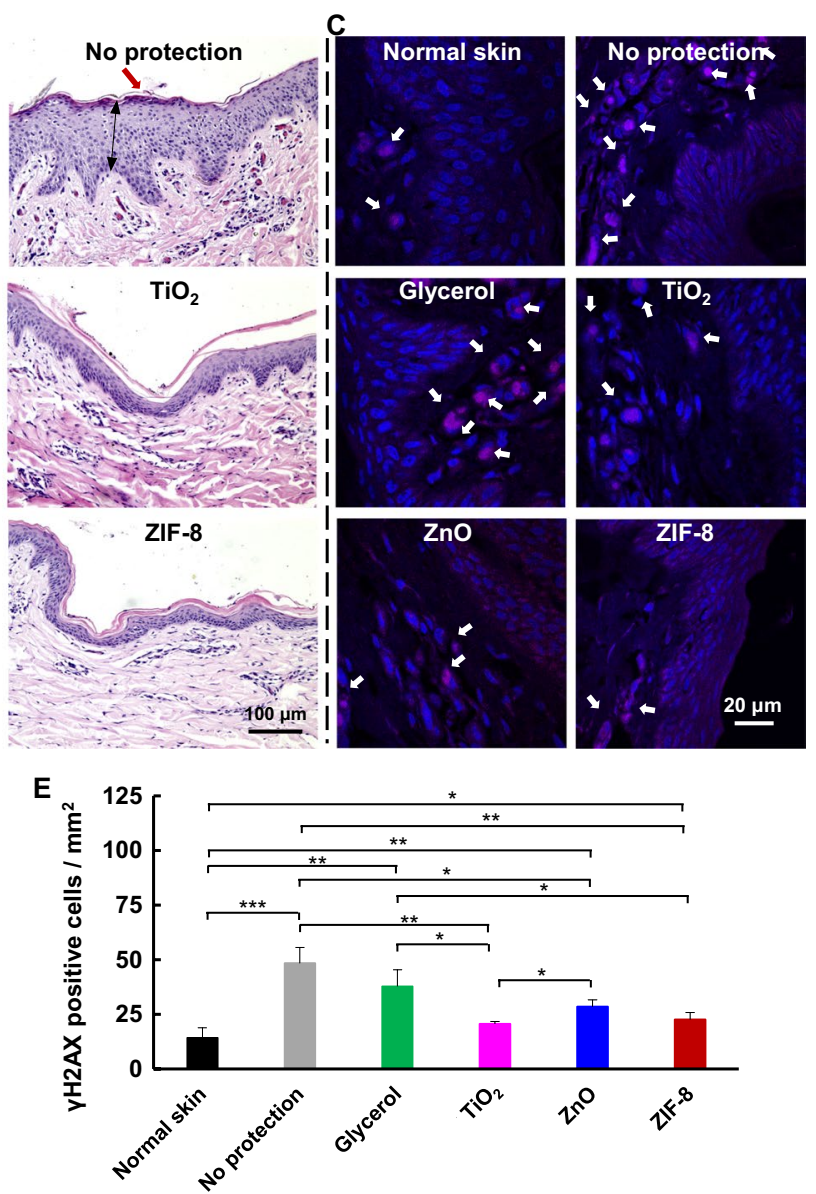

Fig. 5 Photoprotective effects on pig skin. A Representative digital images of pig skin after pre-protection and subsequent UV exposure. Fewer erythema was observed for ZIF-8 group, compared to no protection group. B Photographs of skin with H\&E staining after pre-protection and subsequent UV irradiation. (Red arrows point to parakeratosis.) $\mathbf{C} \gamma-\mathrm{H}_{2} \mathrm{AX}$ immunofluorescence images of skin sections after pre-protection and subsequent UV exposure. (Nucleus: blue; $\gamma-\mathrm{H}_{2} \mathrm{AX}$ : red; White arrows point to $\mathrm{Y}^{-} \mathrm{H}_{2} \mathrm{AX}{ }^{+}$cells.) D, E Quantitative analysis of (D) epidermal thickness and (E) $\mathrm{Y}-\mathrm{H}_{2} \mathrm{AX}$ positive cells on pig skin with pre-protection and subsequent UV exposure. ZIF-8 inhibited epidermal hyperplasia and $\gamma$ - $\mathrm{H}_{2} \mathrm{AX}$ formation

thickness, skin follicles and sebaceous structure, also were not affected for all groups (Fig. 6A, B). Also, the liver function and kidney function were normal and the tissues, including heart, liver, spleen, lung, and kidney, were not affected after treatments with $\mathrm{TiO}_{2}, \mathrm{ZnO}$, or ZIF-8 (Additional file 1: Figs. S31, 32).

We further investigated the penetration of $\mathrm{TiO}_{2}, \mathrm{ZnO}$, or ZIF-8 into mouse or pig skin and their accumulations in mouse blood, heart, liver, spleen, lung, and kidney by measuring $\mathrm{Zn}$ or $\mathrm{Ti}$ contents remaining in the tissues using inductively coupled plasma-mass spectrometry (ICP-MS). The normal $\mathrm{Zn}$ content in mouse skin was $13.5 \pm 1.5 \mu \mathrm{g} \mathrm{g}^{-1}$ tissue, which was significantly increased to $18.2 \pm 3.0 \mu \mathrm{g} \mathrm{g}^{-1}$ tissue for $\mathrm{ZnO}$ group. This correlates well with previous reports that $\mathrm{Zn}$ ions dissociated from $\mathrm{ZnO}$ could get access into human skin after multiple uses $[10,42]$. However, the $\mathrm{Zn}$ content in mouse skin was kept at normal level after ZIF-8 treatment $\left(15.0 \pm 0.2 \mu \mathrm{g} \mathrm{g}^{-1}\right)$
(Fig. 6C), possibly due to its hydrophobic surface [43]. No obvious increases of $\mathrm{Zn}$ level were observed in mouse blood and main organs (Additional file 1: Fig. S33). The Ti content in normal mouse skin with no treatments was $0.10 \pm 0.03 \mu \mathrm{g} \mathrm{g}^{-1}$ tissue, however, which was slightly but not significantly increased to $0.30 \pm 0.14 \mu \mathrm{g} \mathrm{g} \mathrm{g}^{-1}$ tissue after $\mathrm{TiO}_{2}$ exposure (Fig. 6D). Ti levels in blood and main organs were not affected with $\mathrm{TiO}_{2}$ treatment. (Additional file 1: Fig. S33). We also confirmed skin penetrations on pig, a model for human skin due to the similar skin morphology and permeability characteristics [44], which yielded similar results under the same treatment. The $\mathrm{Zn}$ level for $\mathrm{ZnO}$ group was significantly increased to $45.2 \pm 3.5 \mu \mathrm{g} \mathrm{g}^{-1}$ tissue from $17.6 \pm 6.6 \mu \mathrm{g} \mathrm{g}^{-1}$ tissue in normal pig skin. There was no obvious $\mathrm{Zn}$ level increase in the pig skin with glycerol $\left(23.5 \pm 4.3 \mu \mathrm{g} \mathrm{g}^{-1}\right.$ tissue $)$ or ZIF-8 (11.5 $\pm 1.8 \mu \mathrm{g} \mathrm{g}^{-1}$ tissue) treatments (Fig. $\left.6 \mathrm{E}\right) . \mathrm{TiO}_{2}$ 


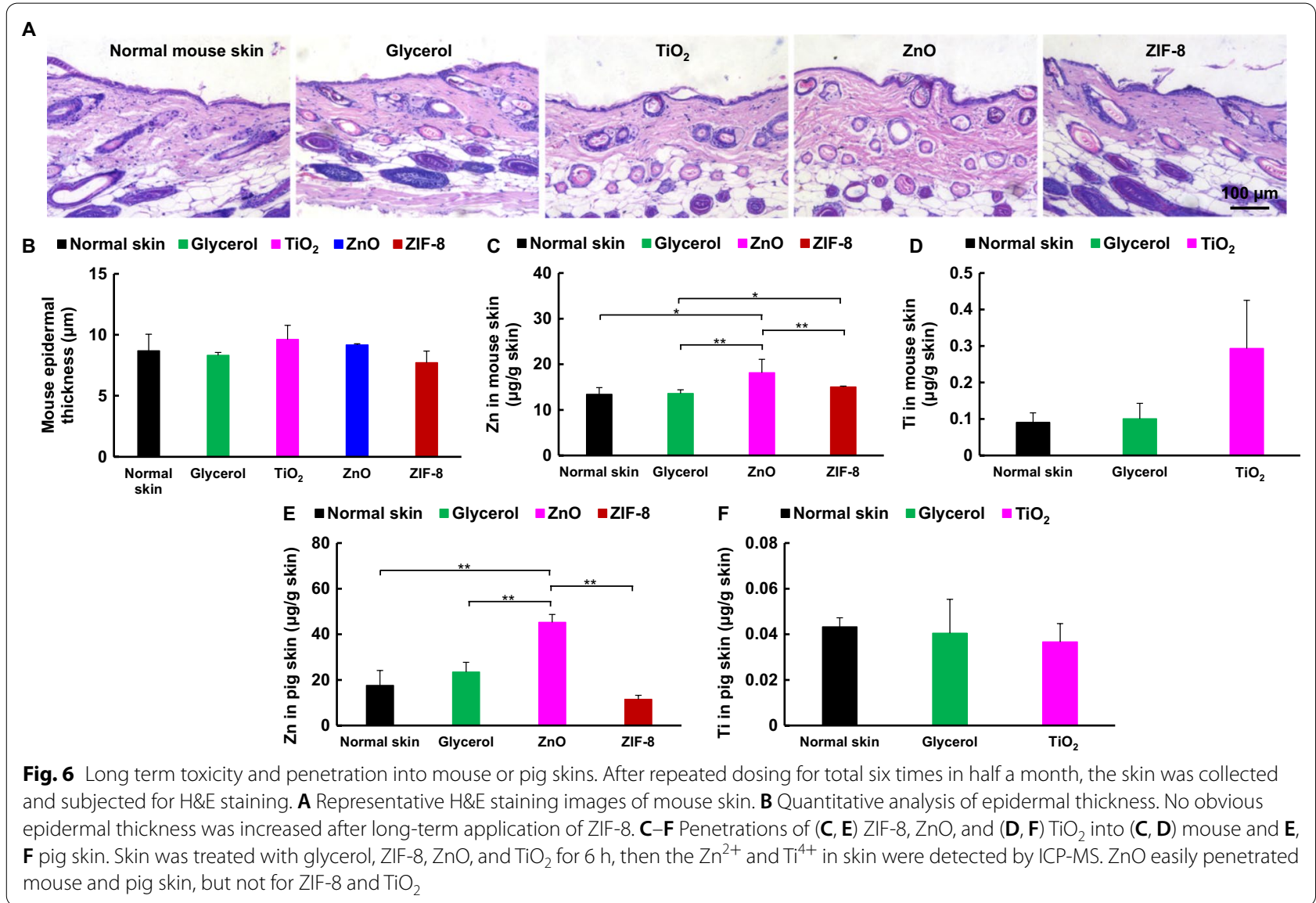

also did not increase Ti level on pig skin, compared to no treatment or glycerol groups (Fig. 6F). The lower skin penetration of ZIF-8 was potentially caused by its hydrophobicity [43], which would potentially contribute to a lower topical toxicity due to the low ZIF-8 level in skin, and further result in a lower systemic risk with less $\mathrm{Zn}$ ions in circulation before ZIF-8 was cleared completely.

\section{Conclusions}

Exposure to solar UV is still a significant health risk for human, and there is still urgent need for safe and effective sunscreens due to the safety and efficacy concerns of current commercially available sunscreens. Herein, we synthesize a serial of Zinc-based MOFs and confirm the UV absorption and reflection can be tuned by choosing different organic ligands. Due to the wide and high UV reflection, ZIF- 8 is selected as model MOFs and the potential as UV filter is evaluated. ZIF-8 exhibits good biocompatibility, low radical production, weak skin penetration, and achieves a high anti-UV efficacy on both mouse and pig skin, respectively, suggesting ZIF-8 could be a potential sunscreen surrogate for human with high efficacy and safety. All these results demonstrate that
Zinc-based MOFs could potentially be a suitable platform to develop sunscreens through tuning UV reflectance and other characteristics, such as hydrophobicity, stability, and photocatalytic activity.

\section{Experimental section Materials and animals}

Zinc oxide $(\mathrm{ZnO}, \geq 99.9 \%)$, titanium oxide $\left(\mathrm{TiO}_{2}, \geq 99.9 \%\right)$, zinc acetate dihydrate $\left(\mathrm{Zn}(\mathrm{Ac})_{2} \cdot 2 \mathrm{H}_{2} \mathrm{O}, \geq 99.9 \%\right)$, terephthalic acid $\left(\mathrm{H}_{2} \mathrm{BDC}\right.$, 99\%), N,N-dimethylformamide (DMF, 99.8\%) and 2-methylimidazole (2-MeIM) were obtained from J\&K Chemicals (Beijing, China). Dimethyl sulfoxide- $\mathrm{d}_{6}$ (DMSO$\mathrm{d}_{6}, \geq 99.9 \%$ ) were purchased from Tian in Fuyu Fine Chemical Co., Ltd (Tianjin, China). 4,4'-stilbenedicarboxylic acid $\left(\mathrm{LH}_{2}\right)$ was bought from Flurochem (UK). Dulbecco's modified eagle medium (DMEM), minimum essential medium (MEM) and fetal bovine serum (FBS) were purchased from Thermo Fisher Scientific (Waltham, MA, USA). Thiazolyl blue (MTT) was bought from Biosharp (Hefei, China). IL-1 $\beta$ polyclonal antibody was obtained from Signalway Antibody LLC (College Park, USA). Phospho-histone $\mathrm{H}_{2} \mathrm{AX}$ (Ser139) antibody $\left(\gamma-\mathrm{H}_{2} \mathrm{AX}\right)$ was bought from Affinity Biosciences (Cincinnati, USA). Anti-thymine dimer antibody 
(cyclobutane pyrimidine dimers, CPDs) was obtained from Sigma-Aldrich (Louis, USA). Masson's trichrome staining kit was purchased from Beijing Solarbio Science \& Technology (Beijing, China). Annexin V-FITC/PI apoptosis detection kit was bought from Procell Life Science \& Technology (Wuhan, China). 2,7-Dichlorofluorescein Diacetate (DCFHDA) probe kit and DNA damage assay kit were obtained from Nanjing Jiancheng Bioengineering Institute (Nanjing, China). UVB light with a peak emission at $308 \mathrm{~nm}$ was bought from Sankyo Denki Co. (Tokyo, Japan).

Human immortalized epidermal keratinocytes (HaCaTs) were purchased from China Center for Type Culture Collection (CCTCC, Wuhan, China) and cultured in DMEM with 10\% FBS and 1\% antibiotics. Human epithelial keratinocytes (HEKas) were obtained from Jennio Biotech (Guangzhou, China) and reserved in MEM medium with $10 \%$ FBS and $1 \%$ antibiotics. Both cells were placed in a humidified incubator with $5 \% \mathrm{CO}_{2}$ at $37^{\circ} \mathrm{C}$.

Male BALB/c mice (6 weeks) were obtained from Laboratory Animal Centre of Guangzhou University of Chinese Medicine. Male Ba-Ma miniature pig (2-3 months) was bought from Dongguan Songshan Lake Laboratory Animal Technology Co., Ltd (Guangdong, China). All the protocols for animal experiments were approved by the Animal Ethics Committee of Southern Medical University, China. (Approval number of the laboratory: L2018244).

\section{Instruments and methodologies}

Powder X-ray diffraction (PXRD) was performed on Bruker D8 advance (Bruker Corporation, Billerica, USA) at the speed of $10^{\circ} \mathrm{min}^{-1}$ with an angle range of $5^{\circ}-60^{\circ}$. ${ }^{1} \mathrm{H}$ NMR spectra were recorded on $400 \mathrm{MHz}$ Bruker (Bruker Corporation, Billerica, USA). Fourier transform infrared (FT-IR) spectra from $\mathrm{KBr}$ pellets were carried out using a Nicolet iS10 spectrometer (Thermo, Waltham, MA, USA). Elemental analysis was performed on an Elementar Vario-EL Cube CHNS elemental analyzer (Vario EL cube, Hanau, Germany). Transmission electron microscope (TEM) imaging was acquired on Hitachi H-7650 microscope (80 kV, Hitachi, Tokyo, Japan). $\mathrm{N}_{2}$ isotherm measurements were carried out on ASAP 2460 (Micromeritics instrument Ltd., GA, Norcross, USA) at $77 \mathrm{~K}$ with $20-100 \mathrm{mg}$ of sample per measurement. Inductively coupled plasma mass spectrometry (ICP-MS) was performed on Agilent 7700 (Agilent Technologies, Inc., Santa Clara, USA). X-ray photoelectron spectroscopy (XPS) were measured using K-Alpha (Thermo Scientific, Waltham, MA, USA). Thermogravimetric analysis (TGA) was acquired on TGA 5500 from
30 to $780{ }^{\circ} \mathrm{C}$ at a speed of $5{ }^{\circ} \mathrm{C} \mathrm{min}{ }^{-1}$ (TA Instruments, New Castle, USA). UV-visible diffuse-reflectance spectrum were performed from $\mathrm{BaSO}_{4}$ pellets on Lambda 950 (PerkinElmer Inc., Waltham, USA) equipped with photometric integrating sphere $(150 \mathrm{~mm}$ Int. sphere). The zeta potentials of $\mathrm{Zn}$-based MOFs were measured using Zetasizer Nano ZS (Malvern Panalytical, UK). To measure electron paramagnetic resonance (EPR), $\mathrm{TiO}_{2}, \mathrm{ZnO}$, or ZIF-8 $\left(2 \mathrm{~mL}, 800 \mu \mathrm{g} \mathrm{mL}^{-1}\right)$ were mixed with free radical catcher $\alpha$-(4-Pyridyl N-oxide)-N-tert-butylnitrone (POBN, $38.8 \mathrm{mg}$ ), irradiated with UV (200-400 nm) for $10 \mathrm{~min}$ at $25 \pm 0.1{ }^{\circ} \mathrm{C}$ under standard atmospheric pressure, and analyzed using a A300 spectrometer (Bruker Corporation, Billerica, USA). The samples at $800 \mu \mathrm{g} \mathrm{mL}$ but not $50 \mu \mathrm{g} \mathrm{mL}^{-1}$, were selected for EPR measurement, because ROS signal was too low to be detected at $50 \mu \mathrm{g} \mathrm{mL}{ }^{-1}$, though ZIF-8 and $\mathrm{TiO}_{2}$ could protect skin cells against UV damage at $50 \mu \mathrm{g} \mathrm{mL}^{-1}$. (Additional file 1 : Fig. S14).

\section{The synthesis and characterization of MOFs}

ZIF-8: ZIF-8 with various sizes were synthesized according to previously reported methods with minor modifications $[45,46]$. Briefly, $\mathrm{Zn}(\mathrm{Ac})_{2} \cdot 2 \mathrm{H}_{2} \mathrm{O}\left(2.28 \times 10^{-1} \mathrm{~mol} \mathrm{~L}^{-1}\right.$ in DMF, $2 \mathrm{~mL}$ ) were added with various ratios of $\mathrm{Zn}^{2+}$ to 2-MeIM ( $4 \mathrm{~mL}$ of DMF, $2.28 \times 10^{-1} \mathrm{~mol} \mathrm{~L}^{-1}$ for ZIF-8 $1: 2,5.71 \times 10^{-1} \mathrm{~mol} \mathrm{~L}^{-1}$ for ZIF-8 $1: 5,9.14 \times 10^{-1} \mathrm{~mol} \mathrm{~L}^{-1}$ for ZIF-8 1:8, $18.28 \times 10^{-1} \mathrm{~mol} \mathrm{~L}^{-1}$ for ZIF-8 1:16) under stirring at $450 \mathrm{rpm}$ to synthesize ZIF-8 with different sizes. After $7.5 \mathrm{~h}$, the reaction solution was centrifuged at $8000 \mathrm{rpm}$ for $2 \mathrm{~min}$ and washed with DMF $(5 \mathrm{~mL})$ and ethanol $(5 \mathrm{~mL})$ for 2 times, respectively. The samples were resuspended with ethanol and stored at $-80^{\circ} \mathrm{C}$ for further use.

TEM, ${ }^{1} \mathrm{H}$ NMR, PXRD, XPS, and $\mathrm{N}_{2}$ isotherm were conducted to confirm the structure of ZIF-8.

ZIF-8 1:2: ${ }^{1} \mathrm{H}$ NMR (DMSO- $\left.\mathrm{d}_{6} / \mathrm{D}_{2} \mathrm{SO}_{4}(9: 1, \mathrm{v} / \mathrm{v})\right): 7.49$ (s, $2 \mathrm{H}$, Imidazole $\mathrm{H}$ ), 2.60 (s, $3 \mathrm{H},-\mathrm{CH}_{3}$ ). Yield: $29.7 \%$. BET surface area was $1237.8 \mathrm{~m}^{2} \mathrm{~g}^{-1}$. Pore size: 9.3$15.0 \AA$. XPS data also revealed the successful synthesis of ZIF-8 1:2 (Additional file 1: Fig. S3).

ZIF-8 1:5: ${ }^{1} \mathrm{H}$ NMR (DMSO-d $\left.{ }_{6} / \mathrm{D}_{2} \mathrm{SO}_{4}(9: 1, \mathrm{v} / \mathrm{v})\right): 7.49$ (s, $2 \mathrm{H}$, Imidazole $\mathrm{H}), 2.56\left(\mathrm{~s}, 3 \mathrm{H},-\mathrm{CH}_{3}\right)$. Yield: $19.1 \%$. BET surface area was $1306.9 \mathrm{~m}^{2} \mathrm{~g}^{-1}$. Pore size: 9.3$15.0 \AA$ A XPS data also revealed the successful synthesis of ZIF-8 1:5 (Additional file 1: Fig. S4).

ZIF-8 1:8: ${ }^{1} \mathrm{H}$ NMR (DMSO-d $\left.6 / \mathrm{D}_{2} \mathrm{SO}_{4}(9: 1, \mathrm{v} / \mathrm{v})\right): 7.38$ (s, $2 \mathrm{H}$, Imidazole $\mathrm{H}), 2.48$ (s, $3 \mathrm{H},-\mathrm{CH}_{3}$ ). Yield: $19.0 \%$. BET surface area was $1566.8 \mathrm{~m}^{2} \mathrm{~g}^{-1}$, which was similar to the reported values, potentially due to the high crystallinity and the excellent activation before $\mathrm{N}_{2}$ isotherm 
measurement. [47, 48] Pore size: 9.3-16.0 A. XPS data also revealed the successful synthesis of ZIF-8 1:8 (Additional file 1: Fig. S5).

ZIF-8 1:16: ${ }^{1} \mathrm{H}$ NMR (DMSO- $\mathrm{d}_{6} / \mathrm{D}_{2} \mathrm{SO}_{4}(9: 1, \mathrm{v} / \mathrm{v})$ ): 7.49 (s, $2 \mathrm{H}$, Imidazole $\mathrm{H}), 2.50\left(\mathrm{~s}, 3 \mathrm{H},-\mathrm{CH}_{3}\right.$ ). Yield: $15.7 \%$. BET surface area was $1267.4 \mathrm{~m}^{2} \mathrm{~g}^{-1}$. Pore size: 9.3$15.9 \AA$. XPS data also revealed the successful synthesis of ZIF-8 1:16 (Additional file 1: Fig. S6).

ZIF-8 was observed using TEM and the particle sizes were plotted thereafter. The particle size were $164.8 \pm 32.6 \mathrm{~nm}, 102.5 \pm 26.8 \mathrm{~nm}, 82.3 \pm 24.5 \mathrm{~nm}$, and $80.0 \pm 37.7 \mathrm{~nm}$ for ZIF-8 1:2, ZIF-8 1:5, ZIF-8 1:8, ZIF-8 $1: 16$, respectively, confirming the size was decreased with the ratios of $\mathrm{Zn}^{2+}$ to 2-MeIM decreasing (Fig. 1A, Additional file 1: Figs. S1, S7A, B). These were similar to the previous report that ZIF-8 sizes were decreased from 110 to $40 \mathrm{~nm}$ with the ratios of $\mathrm{Zn}^{2+}$ to 2 -MeIM decreasing from 1:2 to 1:16 [46]. However, no obvious ZIF-8 morphology variations were observed, (Fig. 1A, S7A) which were not consistent with the reports that morphologies of ZIF-8 turned from cube to sphere with the ratios of $\mathrm{Zn}^{2+}$ to 2-MeIM decreasing [46]. Possibly due to the decline of particle sizes, UV reflectance, especially for UVB and UVC, was enhanced with the decrease of $\mathrm{Zn}^{2+}$ to 2-MeIM ratios, which reached to the highest value for ZIF-8 1:8. No further enhancement was observed for ZIF-8 1:16, (Additional file 1: Fig. S7C) possibly because size of ZIF-8 1:16 was similar to that of ZIF-8 1:8. So ZIF-8 1:8 was selected as model ZIF-8 in the following experiments.

To study the energy release ways of ZIF-8 after UV exposure, $\mathrm{TiO}_{2}, \mathrm{ZnO}$, or ZIF-8 $\left(150 \mathrm{mg} \mathrm{mL}^{-1}\right.$ in glycerol, $1 \mathrm{~mL}$ ) were irradiated with UVB at the dose of $6.408 \times 10^{4} \mathrm{~J} \mathrm{~m}^{-2}$, thermal images were then taken by FLIR C2 Compact Thermal Camera (FLIR Systems, Wilsonville, USA). After irradiation, the fluorescence intensity of $\mathrm{TiO}_{2}, \mathrm{ZnO}$, and ZIF-8 (50 $\mu \mathrm{g} \mathrm{mL}^{-1}$ in ethanol) were obtained by F97 pro fluorescence spectrophotometer (Lengguang Tech., Shanghai, China) with excitation wavelength at $308 \mathrm{~nm}$.

TEM, PXRD, XPS also were used to confirm the structures of $\mathrm{TiO}_{2}$ and $\mathrm{ZnO}$ (Fig. 1A, Additional file 1: Figs. S8, S9).

MOF-5: MOF- 5 was synthesized as previously reported [49]. $\mathrm{Zn}\left(\mathrm{NO}_{3}\right)_{2} \cdot 6 \mathrm{H}_{2} \mathrm{O}(290 \mathrm{mg}, 1 \mathrm{mmol})$ was added into $\mathrm{H}_{2} \mathrm{BDC}\left(5.0 \times 10^{-2} \mathrm{~mol} \mathrm{~L}^{-1}\right.$ in DMF, $\left.10 \mathrm{~mL}\right)$ and heated at $120^{\circ} \mathrm{C}$ for $21 \mathrm{~h}$. The reaction solution was centrifuged at $8000 \mathrm{rpm}$ for $2 \mathrm{~min}$ and washed with DMF $(5 \mathrm{~mL})$ for 3 times. The sample was stored in ethanol at $-80{ }^{\circ} \mathrm{C}$ for further use. ${ }^{1} \mathrm{H}$ NMR (DMSO- $\mathrm{d}_{6} / \mathrm{D}_{2} \mathrm{SO}_{4}(9: 1, \mathrm{v} / \mathrm{v})$ ): 8.07 (s, 4H, Ar H). Yield: 14.2\%. BET surface area: 741.5 $\mathrm{m}^{2} \mathrm{~g}^{-1}$. Pore size: $6.5-15.0 \AA$ A. XPS data confirmed the successful synthesis of MOF-5 (Additional file 1: Figs. $\mathrm{S} 10, \mathrm{~S} 13)$.

IRMOF-1: IRMOF-1 was synthesized according to previously reported method [50, 51]. Briefly, $\mathrm{Zn}\left(\mathrm{NO}_{3}\right)_{2} \cdot 6 \mathrm{H}_{2} \mathrm{O}(10 \mathrm{mg}, 0.034 \mathrm{mmol})$ was added into $\mathrm{H}_{2} \mathrm{BDC}$ solution $\left(2.7 \times 10^{-2} \mathrm{~mol} \mathrm{~L}^{-1}\right.$ in DMF, $\left.10 \mathrm{~mL}\right)$, and heated at $100{ }^{\circ} \mathrm{C}$ for $18 \mathrm{~h}$. The crystals were centrifuged at $8000 \mathrm{rpm}$ for $2 \mathrm{~min}$ and washed with DMF $(5 \mathrm{~mL})$ and ethanol $(5 \mathrm{~mL})$ for 3 times, respectively. The sample was stored in ethanol at $-80{ }^{\circ} \mathrm{C}$ for further use. ${ }^{1} \mathrm{H}$ NMR $\left(\right.$ DMSO $\left.-\mathrm{d}_{6} / \mathrm{D}_{2} \mathrm{SO}_{4}(9: 1, \mathrm{v} / \mathrm{v})\right): 8.07$ (s, 4H, Ar H). Yield: $55.2 \%$. BET surface area: $799.2 \mathrm{~m}^{2} \mathrm{~g}^{-1}$. Pore size: 6.0 $25.0 \AA$. XPS data also revealed the successful synthesis of IRMOF-1 (Additional file 1: Figs. S11, S13).

$Z_{3} L_{3}(D M F)_{2}: Z_{3} L_{3}(D M F)_{2}$ was synthesized following previously reported methods [12]. $\mathrm{Zn}\left(\mathrm{NO}_{3}\right)_{2} \cdot 6 \mathrm{H}_{2} \mathrm{O}$ (209.2 mg, $0.7 \mathrm{mmol})$ was added to $\mathrm{LH}_{2}\left(9.14 \times 10^{-1} \mathrm{~mol}\right.$ $\mathrm{L}^{-1}$ in DMF, $20 \mathrm{~mL}$ ), heated at $75^{\circ} \mathrm{C}$ for $16 \mathrm{~h}$ and followed by heating at $85^{\circ} \mathrm{C}$ for $4 \mathrm{~h}$. Thereafter, the samples were centrifuged at $8000 \mathrm{rpm}$ for $2 \mathrm{~min}$ and the precipitate was washed with DMF $(5 \mathrm{~mL})$ and ethanol $(5 \mathrm{~mL})$ for 3 times, respectively. The sample was stored in ethanol at $-80{ }^{\circ} \mathrm{C}$ for further use. ${ }^{1} \mathrm{H}$ NMR (DMSO- $\mathrm{d}_{6} / \mathrm{D}_{2} \mathrm{SO}_{4}(9: 1$, v/v)): $7.94(\mathrm{~s}, 2 \mathrm{H}, \operatorname{Ar~H}), 7.82(\mathrm{~s}, 2 \mathrm{H}, \operatorname{Ar} \mathrm{H}), 7.49$ (s, 2H, $\mathrm{C}=\mathrm{CH}), 2.93\left(\mathrm{~S},-\mathrm{CH}_{3}, 3 \mathrm{H}\right), 2.77\left(\mathrm{~S}, 3 \mathrm{H},-\mathrm{CH}_{3}\right)$. Yield: $12.8 \%$. BET surface area: $910.1 \mathrm{~m}^{2} \mathrm{~g}^{-1}$. Pore size: $6.4-$ $11.8 \AA$. XPS data also revealed the successful synthesis of $\mathrm{Zn}_{3} \mathrm{~L}_{3}(\mathrm{DMF})_{2}$ (Additional file 1: Fig. S12, 13).

The degradations of MOFs: The degradation of $\mathrm{Zn}$ based MOFs in artificial sweat was assessed as previously reported. Briefly, ZIF-8 1:8 (10 mg, $0.5 \mathrm{mg})$, MOF-5 (0.5 mg), IRMOF-1 (0.5 mg), and $\mathrm{Zn}_{3} \mathrm{~L}_{3}(\mathrm{DMF})_{2}$ $(0.5 \mathrm{mg})$ dispersed in glycerol were sealed into dialysis tubes, followed by an incubation in artificial sweat $(0.5 \%$ $\mathrm{NaCl}, 0.1 \%$ lactic acid, and $0.1 \%$ urea, $\mathrm{pH}=6.5,32{ }^{\circ} \mathrm{C}$ ) at $100 \mathrm{rpm}$. At the predetermined time intervals, artificial sweat samples were collected and renewed with fresh media. The MOF ligands in artificial samples were measured with NanoPhotometer (NP80 Touch, IMPLEN, Germany). ZIF-8 (10 mg) showed the lowest degradation rate $(36.2 \pm 0.5 \%$ of degradation within $24 \mathrm{~h})$, followed by ZIF-8 $(0.5 \mathrm{mg})(46.6 \pm 6.2 \%$ in $4 \mathrm{~h}, 72.0 \pm 8.3 \%$ in $24 \mathrm{~h})$, $\mathrm{Zn}_{3} \mathrm{~L}_{3} \mathrm{DMF}_{2}(0.5 \mathrm{mg})(46.8 \pm 6.8 \%$ in $4 \mathrm{~h}, 80.7 \pm 9.2 \%$ in $24 \mathrm{~h})$, MOF-5 (0.5 mg) (78.3 $\pm 5.0 \%$ in $4 \mathrm{~h})$, and IRMOF-1 $(0.5 \mathrm{mg})(86.8 \pm 5.9 \%$ in $4 \mathrm{~h})$ (Fig. 1E, Additional file 1: Fig. $\mathrm{S} 13 \mathrm{H})$.

In vitro SPF measurement: $\mathrm{TiO}_{2}, \mathrm{ZnO}$, and $\mathrm{ZIF}-8$ were dispersed in ethanol ( $15 \%$ by weight), respectively, and treated with ultrasonication for $10 \mathrm{~min}$. The absorption at 290-320 nm was assessed using NanoDrop 1000 
UV-VIS spectrophotometer (Additional file 1: Fig. S16). SPF values were calculated according to Mansur Eq. (3) below [22]:

$$
S P F_{\text {spectrophotometric }}=\mathrm{CF} \times \sum_{290}^{320} \mathrm{EE}(\lambda) \times \mathrm{I}(\lambda) \times \operatorname{Abs}(\lambda)
$$

where $C F=$ correction factor $(10)$, EE $(\lambda)=$ erythemal effect caused by the radiation with $\lambda$ wavelength, I $(\lambda)=$ solar intensity with $\lambda$ wavelength, Abs $(\lambda)=$ absorbance of samples. EE $\times I$ are constants as previously reported [23].

In vitro cytotoxicity assay $\mathrm{HaCaTs}$ or HEKas were seeded $\left(2 \times 10^{4}\right.$ cells per well) into 96-well plates and incubated for $24 \mathrm{~h}$. Thereafter, the cells were treated with saline or various concentrations $\left(1-100 \mu \mathrm{g} \mathrm{m}^{-1}\right)$ of $\mathrm{TiO}_{2}, \mathrm{ZnO}$, or $\mathrm{ZIF}-8$ for $24 \mathrm{~h}$ and then incubated with MTT solution $\left(0.5 \mathrm{mg} \mathrm{mL}^{-1}\right)$ at $37{ }^{\circ} \mathrm{C}$ for $4 \mathrm{~h}$. Finally, DMSO $(200 \mu \mathrm{L})$ was added to dissolve the resulted crystal and the absorbance at $570 \mathrm{~nm}$ were measured using a microplate reader (Multiskan FC, Thermo Scientific, Waltham, MA USA). Cell viability was expressed as a percentage of the absorbance to that of the control experiment without treatment.

Cell apoptosis assay Cells were seeded into 12-well plates $\left(3 \times 10^{5}\right.$ cells per well $)$ and incubated for $24 \mathrm{~h}$. After treated with $\mathrm{TiO}_{2}, \mathrm{ZnO}$, or ZIF-8 $\left(60 \mu \mathrm{g} \mathrm{mL} \mathrm{m}^{-1}\right)$ (HaCaTs for $12 \mathrm{~h}$ and HEKas for $8 \mathrm{~h}$ ), cells were photographed using a microscope with white light. Thereafter, cells were harvested, fixed with $4 \%$ paraformaldehyde at $4{ }^{\circ} \mathrm{C}$ for $30 \mathrm{~min}$, permeabilized in $1 \%$ Triton-X 100 for another $30 \mathrm{~min}$, and then stained with DAPI for $20 \mathrm{~min}$. The stained cells were examined using fluorescence microscope (DMI8, Leica, Germany).

Cell apoptosis also was assessed using flow cytometry. Cells were grown in 6-well plates at a density of $1 \times 10^{6}$ cells per well and incubated to complete adhesion. Then, the cells were treated with $\mathrm{TiO}_{2}, \mathrm{ZnO}$ or ZIF-8 $\left(60 \mu \mathrm{g} \mathrm{mL}^{-1}, \mathrm{HaCaTs}\right.$ for $12 \mathrm{~h}$ and HEKas for $\left.8 \mathrm{~h}\right)$. Thereafter, the cells were detached with trypsin, centrifuged at $300 \mathrm{~g}$ for $5 \mathrm{~min}$, stained with Annexin V-FITC and propidium iodide (PI) for $20 \mathrm{~min}$, and analyzed by flow cytometer (CytoFLEX LX, Beckman Coulter Biotechnology Co., California, USA).

Protection against $U V$-induced cell death The cell viability of $\mathrm{HaCaTs}$ or HEKas after exposure with various UV doses for $24 \mathrm{~h}$ was first assessed by MTT assay. Around $50 \%$ cell growth inhibition was achieved at UV doses of $35 \mathrm{~mJ} \mathrm{~cm} \mathrm{~cm}^{-2}$ for $\mathrm{HaCaTs}$ and $75.6 \mathrm{~mJ} \mathrm{~cm}^{-2}$ for HEKas (Additional file 1: Fig. S17). Also, the optimized UV doses are similar to the previously reported UVB irradiation doses $\left(30\right.$ or $50 \mathrm{~mJ} \mathrm{~cm}{ }^{-2}$ ) for cells $[52,53]$. Thus, the two UV doses were used in the following protection experiments. HaCaTs or HEKas $(30 \mu \mathrm{L}$ of medium per well) in 96-well plates were treated with $\mathrm{TiO}_{2}, \mathrm{ZnO}$ or ZIF-8 at concentrations of $50 \mu \mathrm{g} \mathrm{mL}{ }^{-1}$ or $60 \mu \mathrm{g} \mathrm{mL}{ }^{-1}$ for 15 min, irradiated with UV lamp (emission peak $308 \mathrm{~nm}$, Sankyo Denki Co., Taiwan, China) at the optimized doses, washed with PBS to remove the nanoparticles and incubated in fresh complete medium for another $24 \mathrm{~h}$. The cell viability was then assessed using MTT assay.

Protection against DNA damage caused by UV irradiation Comet assay was used to determine the photoprotective effect of ZIF-8 to HaCaTs or HEKas. To optimize UV doses, cells were seeded into 12 -well plates $\left(5 \times 10^{5}\right.$ cells per well) and incubated for $24 \mathrm{~h}$. Thereafter, cells were exposed to four UV doses $\left(84,98,114\right.$ or $126 \mathrm{~mJ} \mathrm{~cm}^{-2}$ for HaCaTs and 38.5, 52.5, 66.5 or $84 \mathrm{~mJ} \mathrm{~cm}^{-2}$ for HEKas) and incubated with $1 \mathrm{~mL}$ of complete medium for another $2 \mathrm{~h}$. Cells were collected, mixed with $0.7 \%$ low melting point agarose. The cell suspensions $(40 \mu \mathrm{L})$ were added onto slides with $1 \%$ normal melting point agarose. The slides were soaked in lysis buffer $\left(4^{\circ} \mathrm{C}\right)$ for $1 \mathrm{~h}$, gently washed with PBS, immersed in electrophoresis buffer for $18 \mathrm{~min}$ to allow DNA denaturation, and subjected to electrophoresis for $30 \mathrm{~min}(25 \mathrm{~V}, 200 \mathrm{~mA}$, Horizontal electrophoresis system, DYY-6C, Beijing Six-one Instrument plant, Beijing, China). Subsequently, the samples were neutralized with Tris- $\mathrm{HCl}(\mathrm{pH} 7.5,5 \mathrm{~min} \times 3$ times), stained with PI for $10 \mathrm{~min}$, photographed by Leica fluorescence microscope, and analyzed by Comet Assay Software Project (CASP). Obvious DNA tails could be observed for HaCaTs and HEKas after UV exposure at $114 \mathrm{~mJ} \mathrm{~cm}{ }^{-2}$ and $66.5 \mathrm{~mJ} \mathrm{~cm}^{-2}$, respectively (Additional file 1: Fig. S18). So, the corresponding UV doses were selected for the following cell protection test.

To assess the protective effect against DNA damage, $\mathrm{HaCaTs}$ or HEKas were pretreated with $\mathrm{TiO}_{2}, \mathrm{ZnO}$, or ZIF-8 at the concentration of $60 \mu \mathrm{g} \mathrm{mL}^{-1}$ for $15 \mathrm{~min}$

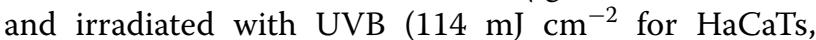
$66.5 \mathrm{~mJ} \mathrm{~cm}^{-2}$ for HEKas). Comet assay was then performed as above mentioned.

Intracellular production of ROS $\mathrm{HaCaT}$ cells and $\mathrm{HeKa}$ cells $\left(2.5 \times 10^{5}\right)$ were seeded in 24-well plates and incubated for $24 \mathrm{~h}$, pretreated with $\mathrm{TiO}_{2}, \mathrm{ZnO}$, or ZIF-8 at the concentration of $60 \mu \mathrm{g} \mathrm{mL}^{-1}$ for $15 \mathrm{~min}$ and irradi-

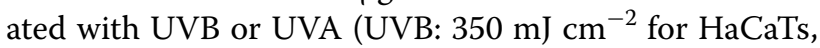
$180 \mathrm{~mJ} \mathrm{~cm}{ }^{-2}$ for HEKas; UVA: $100 \mathrm{~mJ} \mathrm{~cm}^{-2}$ for HaCaTs, $60 \mathrm{~mJ} \mathrm{~cm}^{-2}$ for HEKas). Thereafter, the cells were treated with $2^{\prime}, 7^{\prime}$-dichlorofluorescein diacetate (DCFH-DA) reactive oxygen species assay kits following the manufacture instructions. The intracellular ROS levels were assessed using confocal fluorescent microscopy and flow cytometry. (Negative control: Cells without UV exposure and without UV protection; Positive control: Cells with UV exposure but without UV protection.) 
Protective effects on mice and pig skin The dorsal skin of each male BALB/c mouse (6-weeks old) was demarcated into six squares $(1 \mathrm{~cm} \times 1 \mathrm{~cm})$, exposed to $\mathrm{UV}$ at various doses $\left(172,206\right.$, or $240 \mathrm{~J} \mathrm{~m}^{-2}$, respectively) to optimize UV dose. After three days, obvious erythema was observed for the skin with UV exposure at dose of $206 \mathrm{~J} \mathrm{~m}^{-2}$ and this UV dose was selected for further use (Additional file 1: Fig. S23). To optimize ZIF-8 dose, the skin squares were treated with ZIF-8 $(1.5 \mu \mathrm{L})$ for $15 \mathrm{~min}$ with concentrations of $10 \%, 15 \%$, or $20 \%$, respectively, and exposed to UV at $206 \mathrm{~J} \mathrm{~m}^{-2}$. After three days, no obvious erythema was observed for the skin with ZIF-8 protection at the dose of $15 \%$, so this ZIF- 8 dose was selected for further use (Additional file 1: Fig. S24). To assess anti-UV effect, the skin squares were randomly treated with glycerol, $\mathrm{TiO}_{2}, \mathrm{ZnO}$, or ZIF-8 $(15 \%, 1.5 \mu \mathrm{L})$ for $15 \mathrm{~min}$, exposed to UVB radiation $\left(206 \mathrm{~mJ} \mathrm{~cm} \mathrm{~cm}^{-2}\right)$ and photographed after 3 days. The mice were fed separately during the experiment. At the end time point, the skin was fixed with $4 \%$ paraformaldehyde, embedded in paraffin, sectioned with a thickness of $4 \mu \mathrm{m}$ and subjected to Hematoxylin and Eosin (H\&E) staining, Masson's trichrome staining, or immunohistochemistry for CPD and IL-1 $\beta$, respectively. The skin without protection was used as control. In these tests, the mouse and pig skin were pretreated with filters for 15 min following the World Health Organization (WHO) recommendation with minor changes, with the purpose to not affect the SPF value of these sunscreens $[54,55]$.

In vivo ROS in mouse skin after UV exposure The dorsal skin $(1 \mathrm{~cm} \times 1 \mathrm{~cm})$ of each mouse was treated with glycerol $(1.5 \mu \mathrm{L}), \mathrm{TiO}_{2}, \mathrm{ZnO}$, and $\mathrm{ZIF}-8(15 \%, 1.5 \mu \mathrm{L})$ for $15 \mathrm{~min}$, respectively. Thereafter, the skin was exposed with UVB $\left(18 \mathrm{~mJ} \mathrm{~m}^{-2}\right)$ and collected after $3 \mathrm{~h}$. After that, the cells were detached from the skin and stained using DCFH-DA. The ROS level was assessed using flow cytometry.

In vivo penetration into mouse skin The dorsal skin of the mice was demarcated into five squares $(1 \mathrm{~cm} \times 1 \mathrm{~cm})$ after the hair was removed and randomly treated for $6 \mathrm{~h}$ with glycerol $(1.5 \mu \mathrm{L}), \mathrm{TiO}_{2}, \mathrm{ZnO}$, and $\mathrm{ZIF}-8(15 \%$, $1.5 \mu \mathrm{L}$ ), respectively. During the experiment, the mice were fed with $0.1 \mathrm{~mL}$ of water per hour by intragastric administration and heated on a pad at $37^{\circ} \mathrm{C}$. After that, the skins were topically washed with PBS $\left(37^{\circ} \mathrm{C}\right.$, 5 min $\times 3$ times) and dried. The skin samples were collected and stripped for 30 times with tape, wiped with ethanol swabs for 3 times, weighed, and lysed with $70 \%$ $\mathrm{HNO}_{3}$ for $12 \mathrm{~h}$. The levels of $\mathrm{Zn}^{2+}$ and $\mathrm{Ti}^{4+}$ in the skin were measured using ICP-MS. The skin without treatment was used as control.

In vivo long-term toxicity The mice were randomly divided into five groups as above mentioned. The dorsal skin was gently outlined into $2 \mathrm{~cm} \times 2 \mathrm{~cm}$ squares using purple surgical marker and treated with glycerol $(6 \mu \mathrm{L})$, $\mathrm{TiO}_{2}$, $\mathrm{ZnO}$ or ZIF-8 (15\%, $\left.6 \mu \mathrm{L}\right)$ for 15 min every other day and 6 times in total. Three days after the last treatment, the skin, heart, liver, spleen, lung, kidney was collected, the paraffin section and the subsequent H\&E staining were performed. Also, the Ti or $\mathrm{Zn}$ levels in heart, liver, spleen, lung, kidney, or blood were measured using ICP-MS. Additionally, blood biochemical parameters were measured to assess the system toxicity, including alkaline phosphatase (AKP), aspartate aminotransferase (AST), and alanine transaminase (ALT) for liver function, and creatinine (CRE) and serum urea nitrogen (BUN) for kidney function.

In vivo anti-UV effect on pig Ba-Ma miniature pig (6090 days old, male) was anesthetized with $3.5 \%$ sodium pentobarbital $\left(0.3 \mathrm{~mL} \mathrm{~kg}^{-1}\right)$ and $10 \%$ xylazine hydrochloride injection $\left(0.3 \mathrm{~mL} \mathrm{~kg}^{-1}\right)$. During the experiment, the pig was given with supplemental anesthetics when necessary. The skin was demarcated into squares $(1 \mathrm{~cm} \times 1 \mathrm{~cm})$ after the dorsal hair was removed. Thereafter, the skin squares were exposed to UV at various doses (442, 544, or $646 \mathrm{~J} \mathrm{~m}^{-2}$, respectively) to optimize UV dose. After one day, obvious erythema was induced by UV exposure at dose of $544 \mathrm{~J} \mathrm{~m}^{-2}$ and this UV dose was selected for further use (Additional file 1: Fig. S28). To optimize ZIF- 8 dose, the skin squares were treated to ZIF-8 for 15 min with $1.5 \mu \mathrm{L}$ of ZIF-8 at concentrations of $10 \%, 15 \%$, or $20 \%$, respectively, and exposed to $\mathrm{UV}$ at $544 \mathrm{~J} \mathrm{~m}^{-2}$. After one day, erythema was successfully inhibited by ZIF-8 protection with concentration of $15 \%$, however, obvious erythema could still be seen for the skin with ZIF-8 treatment at $10 \%$, so ZIF-8 dose at $15 \%$ was selected for further use (Additional file 1: Fig. S29). To assess anti-UV effect of ZIF-8 on pig, the skin squares were randomly pretreated with glycerol $(1.5 \mu \mathrm{L}), \mathrm{TiO}_{2}, \mathrm{ZnO}$, or ZIF-8 $(15 \%, 1.5 \mu \mathrm{L})$ for $15 \mathrm{~min}$,

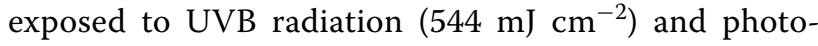
graphed again after $24 \mathrm{~h}$. The skin was collected, and the paraffin section was performed, followed by H\&E staining, Masson's trichrome staining, and $\gamma \mathrm{H}_{2} \mathrm{AX}$ immunofluorescence staining. The skin without protection was used as control.

Ex vivo penetration into pig skin Fresh pig skin was cut into pieces $(1 \mathrm{~cm} \times 1 \mathrm{~cm})$, topically treated with glycerol, $\mathrm{TiO}_{2}, \mathrm{ZnO}$ or $\mathrm{ZIF}-8$ (1.5 $\left.\mu \mathrm{L}, 15 \%\right)$, respectively, and incubated at $32{ }^{\circ} \mathrm{C}$ in a humidity chamber for $6 \mathrm{~h}$. The levels of $\mathrm{Zn}^{2+}$ and $\mathrm{Ti}^{4+}$ in the skins were assessed using ICP-MS after treatment following the methods in the section of "In vivo ZIF-8 penetration into mouse skin". The skin with no treatment was used as control. 


\section{Abbreviations}

MOFs: Metal-organic frameworks; ROS: Reactive oxygen species; Egs: Bandgap energies; SPF: Sun protection factor; RT: Room temperature; ZnO: Zinc oxide; $\mathrm{TiO}_{2}$ : Titanium oxide; $\mathrm{Zn}(\mathrm{Ac})_{2} \cdot 2 \mathrm{H}_{2} \mathrm{O}$ : Zinc acetate dihydrate; $\mathrm{H}_{2} \mathrm{BDC}$ : Terephthalic acid; DMF: N,N-dimethylformamide; 2-MelM: 2-Methylimidazole; DMSO$d_{6}$ : Dimethyl sulfoxide- $d_{6} ; \mathrm{LH}_{2}: 4,4$ '-Stilbenedicarboxylic acid; DMEM: Dulbecco's modified eagle medium; MEM: Minimum essential medium; FBS: Fetal bovine serum; MTT: Thiazolyl blue; $\gamma-\mathrm{H}_{2} \mathrm{AX}$ : Phospho-histone $\mathrm{H}_{2} \mathrm{AX}$ (Ser139) antibody; DCFH-DA: 2,7-Dichlorofluorescein diacetate; HaCaTs: Human immortalized epidermal keratinocytes; HEKas: Human epithelial keratinocytes; PXRD: Powder X-ray diffraction; TEM: Transmission electron microscope; ICPMS: Inductively coupled plasma mass spectrometry; XPS: X-ray photoelectron spectroscopy; TGA: Thermogravimetric analysis; EPR: Electron paramagnetic resonance; POBN: a-(4-Pyridyl N-oxide)-N-tert-butylnitrone; PI: Propidium iodide; H\&E: Hematoxylin and Eosin.

\section{Supplementary Information}

The online version contains supplementary material available at https://doi. org/10.1186/s12951-022-01292-1.

Additional file 1: Figure S1. Particle size of $\mathrm{TiO}_{2}, \mathrm{ZnO}$ and $\mathrm{ZIF}-8$. Particle size was measured using TEM and plotted thereafter. The peak sizes for $\mathrm{TiO}_{2}, \mathrm{ZnO}$, and $\mathrm{ZIF}-8$ were $102.1 \mathrm{~nm}, 114.8 \mathrm{~nm}$ and $82.3 \mathrm{~nm}$, respectively. Figure S2. Enlarged figures for (A) Fig. 1C and (B) Fig. 1D. Figure S3. Characterization of ZIF-8 1:2. (A) PXRD pattern. (B) ${ }^{1} \mathrm{H}$ NMR spectrum. (C) XPS spectrum. (D) $\mathrm{N}_{2}$ adsorption and desorption isotherms. (E) Pore size distribution. Figure S4. Characterization of ZIF-8 1:5. (A) PXRD pattern. (B) ${ }^{1} \mathrm{H}$ NMR spectrum. (C) XPS spectrum. (D) $\mathrm{N}_{2}$ adsorption and desorption isotherms. (E) Pore size distribution. Figure S5. Characterization of ZIF-8 1:8. (A) PXRD pattern. (B) ${ }^{1} \mathrm{H}$ NMR spectrum. (C) XPS spectrum. (D) $\mathrm{N}_{2}$ adsorption and desorption isotherms. (E) Pore size distribution. Figure S6. Characterization of ZIF-8 1:16. (A) PXRD pattern. (B) ${ }^{1} \mathrm{H}$ NMR spectrum. (C) XPS spectrum. (D) $\mathrm{N}_{2}$ adsorption and desorption isotherms. (E) Pore size distribution. Figure S7. Physical and chemical characterizations of ZIF-8 $(1: 2,1: 5,1: 16)$. (A) TEM images of ZIF-8 $(1: 2,1: 5,1: 16)$. (B) Particle sizes of ZIF-8 $(1: 2,1: 5,1: 16)$. Particle size was measured using TEM and plotted thereafter. The sizes for ZIF-8 $(1: 2,1: 5,1: 16)$ were $164.8 \pm 32.6 \mathrm{~nm}$ $102.5 \pm 26.8 \mathrm{~nm}$, and $80.0 \pm 37.7 \mathrm{~nm}$, respectively. (C) Diffuse reflection spectra for ZIF-8 (1:2, 1:5, 1:16). UV reflectance, especially for UVB and UVC, was enhanced with decreasing the ratios of $\mathrm{Zn}^{2+}$ to 2-MeIM and reached to the highest value for ZIF-8 1:8. UV reflectance was not further increased ZIF-8 1:16. Figure S8. Characterization of $\mathrm{TiO}_{2}$. (A) PXRD pattern. (B) XPS spectrum. Figure S9. Characterization of ZnO. (A) PXRD pattern. (B) XPS spectrum. Figure S10. Characterization of MOF-5. (A) PXRD pattern. (B) ${ }^{1} \mathrm{H}$ NMR spectrum. (C) XPS spectrum. (D) $\mathrm{N}_{2}$ adsorption and desorption isotherms. (E) Pore size distribution. Figure S11. Characterization of IRMOF-1. (A) PXRD pattern. (B) ${ }^{1} \mathrm{H}$ NMR spectrum. (C) XPS spectrum. (D) $\mathrm{N}_{2}$ adsorption and desorption isotherms. (E) Pore size distribution. Figure S12. Characterization of $Z n_{3} L_{3} D M F_{2}$. (A) PXRD pattern. (B) ${ }^{1} H N M R$ spectrum. (C) XPS spectrum. (D) $\mathrm{N}_{2}$ adsorption and desorption isotherms. (E) Pore size distribution. Figure S13. Physical and chemical characterizations of zinc-based MOFs. (A-C) TEM images. (A) MOF-5. (B) IRMOF-1. (C) $\mathrm{Zn}_{3} \mathrm{~L}_{3} \mathrm{DMF}_{2}$. (D-F) Particle size distributions of MOF-5, IRMOF-1 and $\mathrm{Zn}_{3} \mathrm{~L}_{3} \mathrm{DMF}_{2}$. Particle size was measured using TEM and plotted thereafter. The sizes were $310.6 \pm 142.4 \mathrm{~nm}, 47.1 \pm 13.6 \mathrm{~nm}$, and $256.0 \pm 91.3 \mathrm{~nm}$ for MOF-5, IRMOF-1, and $Z n_{3} L_{3} D_{M} F_{2}$, respectively. (G) The zeta potentials of $\mathrm{TiO}_{2}, \mathrm{ZnO}, \mathrm{ZIF}-8, \mathrm{MOF}-5$, IRMOF-1, and $\mathrm{Zn}_{3} \mathrm{~L}_{3} \mathrm{DMF}_{2}$ were $31.7 \pm 0.6 \mathrm{mV}$, $16.4 \pm 0.7 \mathrm{mV}, 29.5 \pm 0.8 \mathrm{mV},-9.9 \pm 1.5 \mathrm{mV},-7.0 \pm 0.6 \mathrm{mV}$, and $-5.6 \pm 0.6 \mathrm{mV}$, respectively. $(\mathrm{H})$ The degradation of zinc-based MOFs in artificial sweat $\left(\mathrm{pH} 6.5,32^{\circ} \mathrm{C}\right)$. ZIF-8 $(0.5 \mathrm{mg})$ exhibited the lowest degradation rate relative to that of MOF-5 $(0.5 \mathrm{mg})$, IRMOF-1 $(0.5 \mathrm{mg})$, and $\mathrm{Zn}_{3} \mathrm{~L}_{3} \mathrm{DMF}_{2}(0.5 \mathrm{mg})$. Figure S14. EPR spectra of POBN-OH spin abduct signal produced by $\mathrm{TiO}_{2}$ suspensions in ethanol. (A) $\mathrm{TiO}_{2}$ at $800 \mu \mathrm{g} \mathrm{mL}^{-1}$, (B) $\mathrm{TiO}_{2}$ at $50 \mu \mathrm{g} \mathrm{mL}^{-1}$. No obvious EPR signal was detected for $\mathrm{TiO}_{2}$ at $50 \mu \mathrm{g} \mathrm{mL}{ }^{-1}$. Figure S15. EPR spectra of POBN-OH spin abduct signal produced by suspensions of $\mathrm{TiO}_{2}, \mathrm{ZnO}$, and $\mathrm{Zn}$-based MOFs at $800 \mathrm{\mu g} \mathrm{mL}^{-1}$ in ethanol. (A) $\mathrm{TiO}_{2}$, (B) $\mathrm{ZnO}$, (C) ZIF-8, (D) MOF-5, (E) IRMOF-1, (F) $\mathrm{Zn}_{3} \mathrm{~L}_{3} \mathrm{DMF}_{2}$. $\mathrm{ZnO}$ produced most free radical of $\cdot \mathrm{OH}\left(1.3 \times 10^{12}\right.$ spins/ $\left.\mathrm{mm}^{3}\right)$, followed by $\mathrm{TiO}_{2}\left(5.9 \times 10^{11}\right.$ spins $\left./ \mathrm{mm}^{3}\right), \mathrm{MOF}-5\left(4.1 \times 10^{11}\right.$ spins/ $\left.\mathrm{mm}^{3}\right), Z_{3} \mathrm{~L}_{3} \mathrm{DMF}_{2}\left(2.1 \times 10^{11}\right.$ spins $\left./ \mathrm{mm}^{3}\right)$, IRMOF-1 $\left(6.2 \times 10^{10}\right.$ spins $\left./ \mathrm{mm}^{3}\right)$ and ZIF-8 $\left(2.3 \times 10^{10}\right.$ spins $\left./ \mathrm{mm}^{3}\right)$, suggesting Zn-based MOFs induced much less EPR signal compared to $\mathrm{TiO}_{2}$ and $\mathrm{ZnO}$ after UV exposure. Figure S16. UV absorbance of $\mathrm{ZIF-8}, \mathrm{TiO}_{2}, \mathrm{ZnO}$ and 2-MeIM. ZIF-8 showed a higher UV absorbance compared to ZnO. Also, ZIF-8 revealed a higher UVB absorption relative to $\mathrm{TiO}_{2}$, though UVA absorption of is lower. Figure S17. Cell viability of (A) HaCaTs or (B) HEKas after exposed with UV in various doses. Figure S18. Fluorescence images of DNA tail after (A) HaCaTs or (B) HEKas were exposed to UV in various doses. Figure S19. ROS levels in HaCaTs after UVB exposure. (A) Confocal fluorescent images (Blue, nucleus; Green, ROS positive.). (B) Flow cytometry analyses of free radical levels in $\mathrm{HaCaTs}$ with/without protections. HaCaTs with ZIF-8 pretreatment showed no obvious increase of ROS. However, ROS were elevated for the cells without protection or with the protections of $\mathrm{TiO}_{2}$, $\mathrm{ZnO}, \mathrm{MOF}-5$, IRMOF-1 or $\mathrm{Zn}_{3} \mathrm{~L}_{3} \mathrm{DMF}_{2}$. Figure S20. ROS levels in HEKas after UVB exposure. (A) Confocal fluorescence images (Blue, nucleus; Green, ROS positive.) and (B) flow cytometry analyses of free radicals in HEKas with/without protections. HaCaTs with ZIF-8 pretreatment showed less ROS production relative to that for the cells without protection or with the protections of $\mathrm{TiO}_{2}, \mathrm{ZnO}, \mathrm{MOF}-5$, IRMOF-1 or $\mathrm{Zn}_{3} \mathrm{~L}_{3} \mathrm{DMF}_{2}$. Figure S21. ROS levels in $\mathrm{HaCats}$ after UVA exposure. (A) Confocal fluorescent images (Blue, nucleus; Green, ROS). (B) Flow cytometry analyses of free radical level in $\mathrm{HaCats}$ with/without protections. HaCaTs with ZIF-8 pretreatment showed no obvious ROS production. More ROS production were observed in the cells without protection or with the protections of $\mathrm{TiO}_{2}, \mathrm{ZnO}, \mathrm{MOF}-5$, IRMOF-1 or $\mathrm{Zn}_{3} \mathrm{~L}_{3} \mathrm{DMF}_{2}$. Figure S22. ROS measurement in HEKas after UVA exposure. (A) Confocal fluorescent images (Blue, nucleus; Green, ROS.). (B) Flow cytometry analyses of free radicals in HEKas with/without protections. HEKas with ZIF-8 protection showed less ROS production relative to that for the groups of No protection, IRMOF-1, $\mathrm{TiO}_{2}, \mathrm{ZnO}$, MOF-5, or $Z n_{3} L_{3} D M F_{2}$. Figure S23. UV dose optimization on mouse skin. Images of mouse dorsal skin three days after UV exposure at different doses. UV dose of $206 \mathrm{~J} \mathrm{~m}^{-2}$ was selected for further use because erythema was observed at this dose. Figure S24. ZIF-8 dose optimization. Images of mouse skin three days after UV exposure with protections of $\mathrm{TiO}_{2}, \mathrm{ZnO}$, and $\mathrm{ZIF}-8$ at different doses. The dose of $15 \%$ was selected for further in vivo mouse study, because some sunburn was observed for $\mathrm{TiO}_{2}$ and $\mathrm{ZnO}$ mice at this dose, while no obvious erythema was observed for ZIF-8 mice at dose of 15\%. Figure S25. Digital graphs of mouse dorsal skin three days after UV exposure with the protections of $\mathrm{TiO}_{2}, \mathrm{ZnO}$, or $\mathrm{ZIF-8}$. ZIF-8 group showed less ulceration, edema or erythema compared to no protection or glycerol group. Figure S26. ROS in mouse skin after UV exposure. (A) Quantitative and (B) qualitative analyses of free radical level in the skin with/without protections. Figure S27. Microscope photographs of the mouse skin with (A) Masson's Trichrome staining or (B) IL-1B immunohistochemistry. UV disturbed collagen distribution and decreased density for no protection and glycerol groups, while ZIF-8 group showed a normal collagen appearance. ZIF-8 also inhibited the skin expression of IL-1 $\beta$ after UV exposure. Figure S28. UV dose optimization on pig skin. Digital images of pig dorsal skin $24 \mathrm{~h}$ after UV exposure. UV at $544 \mathrm{~J} \mathrm{~m}^{-2}$ could induce obvious erythema. Figure S29. ZIF-8 dose optimization against UV exposure on pig skin. Digital graphs of pig dorsal skin $24 \mathrm{~h}$ after UV exposure with protections of ZIF-8 at different doses. ZIF-8 at 15\% obviously inhibited erythema formation. Figure S30. Digital graphs of pig dorsal skin $24 \mathrm{~h}$ after UV exposure with the protections of $\mathrm{TiO}_{2}, \mathrm{ZnO}$, or ZIF-8. ZIF-8 obviously inhibited erythema formation. Figure S31. Blood biochemical analyses after mice were treated with $\mathrm{TiO}_{2}, \mathrm{ZnO}$, or $\mathrm{ZIF}-8$ for six times in 15 days. (A-C) Serum levels of (A) AKP, (B) ALT, and (C) AST for liver function analyses. (D-E) Serum levels of (D) BUN, and (E) CRE for kidney function analyses. Both liver and kidney functions were not affected by $\mathrm{TiO}_{2}, \mathrm{ZnO}$, or ZIF-8. Figure S32. H\&E images of main tissues after mice were treated with $\mathrm{TiO}_{2}, \mathrm{ZnO}$, or $\mathrm{ZIF}-8$ for six times in 15 days. No obvious tissue damage was observed for heart, liver, spleen, lung, and kidney in all these groups. Figure S33. The accumulations of Ti or $\mathrm{Zn}$ in blood and tissues after $\mathrm{TiO}_{2}, \mathrm{ZnO}$, or $\mathrm{ZIF}-8$ were applied for six times in 15 days. $(A, B)$ Ti levels in $(A)$ heart, liver, spleen, lung, and kidney and $(B)$ blood for the mice with $\mathrm{TiO}_{2}$ treatment. (C, D) $\mathrm{Zn}$ levels in (C) heart, liver, spleen, lung, and kidney and (D) blood for the mice with $\mathrm{ZnO}$ or $\mathrm{ZIF}-8$ treatments. 


\section{Acknowledgements}

This study was supported by National Natural Science foundation of China (No. 31971321, No. 81801815, No. 32001007, No. 31901002), Natural Science Foundation of Guangdong Province (No. 2020A1515010826), Guangzhou Science, Technology and Innovation Commission (No. 202002030498).

\section{Authors' contributions}

XD and JX jointly developed the idea of this project. XD conceived, directed, and oversaw the project. JX and XD designed the experiments and wrote the manuscript. JX did the data analysis of UV reflectance and SPF measurement. HL, CC, TY, ZW performed the experiments with the help of WZ, MW, FZ and JC. HL, CC, TY did the data analysis. JL provided TOC figures. All authors read and approved the final manuscript.

\section{Declarations}

\section{Ethics approval and consent to participate}

All the protocols for animal experiments were approved by the Animal Ethics Committee of Southern Medical University, China. (Approval number of the laboratory: L2018244)

\section{Consent for publication}

All authors have seen the manuscript and approved the submission.

\section{Competing interests}

The authors have declared that no competing interest exists.

\section{Author details}

${ }^{1}$ Translational Medicine Research Center, Zhujiang Hospital, Southern Medical University/The Second School of Clinical Medicine, Southern Medical University, Guangzhou 510515, Guangdong, China. ${ }^{2}$ Cancer Research Institute, School of Basic Medical Sciences, Southern Medical University, Guangzhou 510515, China. ${ }^{3}$ Science and Technology Innovation Center, Guangzhou University of Chinese Medicine, Guangzhou 510405, China. ${ }^{4}$ Department of Pharmacology, School of Pharmacy, Fudan University, Minhang Hospital, Shanghai 201203, China. ${ }^{5}$ Artemisinin Research Center, Institute of Science and Technology, The First Affiliated Hospital, The First Clinical Medical School, Lingnan Medical Research Center, Guangzhou University of Chinese Medicine, Guangzhou 510405, China.

Received: 19 August 2021 Accepted: 2 February 2022

Published online: 19 February 2022

\section{References}

1. D'Orazio J, Jarrett S, Amaro-Ortiz A, Scott T. UV radiation and the skin. Int J Mol Sci. 2013;14(6):12222-48.

2. Tian Z, Yao T, Qu C, Zhang S, Li X, Qu Y. Photolyase-like catalytic behavior of CeO(2). Nano Lett. 2019;19(11):8270-7.

3. Lo JA, Fisher DE. The melanoma revolution: from UV carcinogenesis to a new era in therapeutics. Science (New York, NY). 2014;346(6212):945-9.

4. McSweeney PC. The safety of nanoparticles in sunscreens: an update for general practice. Aust Fam Phys. 2016;45(6):397-9.

5. Deng $Y$, Ediriwickrema A, Yang F, Lewis J, Girardi M, Saltzman WM. A sunblock based on bioadhesive nanoparticles. Nat Mater. 2015:14(12):1278-85.

6. Livraghi S, Corazzari I, Paganini MC, Ceccone G, Giamello E, Fubini $\mathrm{B}$, Fenoglio I. Decreasing the oxidative potential of $\mathrm{TiO}(2)$ nanoparticles through modification of the surface with carbon: a new strategy for the production of safe UV filters. Chem Commun (Camb). 2010;46(44):8478-80

7. Pan Z, Lee W, Slutsky L, Clark RA, Pernodet N, Rafailovich MH. Adverse effects of titanium dioxide nanoparticles on human dermal fibroblasts and how to protect cells. Small. 2009;5(4):511-20.

8. Aditya A, Chattopadhyay S, Gupta N, Alam S, Veedu AP, Pal M, Singh A Santhiya D, Ansari KM, Ganguli M. ZnO nanoparticles modified with an amphipathic peptide show improved photoprotection in skin. ACS Appl Mater Interfaces. 2019;11(1):56-72.
9. Caputo F, De Nicola M, Sienkiewicz A, Giovanetti A, Bejarano I, Licoccia S, Traversa E, Ghibelli L. Cerium oxide nanoparticles, combining antioxidant and UV shielding properties, prevent UV-induced cell damage and mutagenesis. Nanoscale. 2015;7(38):15643-56.

10. Mohammed YH, Holmes A, Haridass IN, Sanchez WY, Studier H, Grice JE, Benson HAE, Roberts MS. Support for the safe use of zinc oxide nanoparticle sunscreens: lack of skin penetration or cellular toxicity after repeated application in volunteers. J Invest Dermatol. 2019;139(2):308-15.

11. Mohammed YH, Haridass IN, Grice JE, Benson HAE, Roberts MS. Bathing does not facilitate human skin penetration or adverse cellular effects of nanoparticulate zinc oxide sunscreens after topical application. J Investig Dermatol. 2020;140(8):1656-9.

12. Usman M, Mendiratta S, Lu KL. Semiconductor metal-organic frameworks: future low-bandgap materials. Adv Mater (Deerfield Beach, Fla.). 2017; 29(6):1605071.

13. Dong R, Han P, Arora H, Ballabio M, Karakus M, Zhang Z, Shekhar C, Adler P, Petkov PS, Erbe A, Mannsfeld SCB, Felser C, Heine T, Bonn M, Feng X, Cánovas E. High-mobility band-like charge transport in a semiconducting two-dimensional metal-organic framework. Nat Mater. 2018;17(11):1027-32.

14. Yang $C$, Dong $R$, Wang $M$, Petkov PS, Zhang Z, Wang M, Han P, Ballabio $M$, Bräuninger SA, Liao Z, Zhang J, Schwotzer F, Zschech E, Klauss HH, Cánovas E, Kaskel S, Bonn M, Zhou S, Heine T, Feng X. A semiconducting layered metal-organic framework magnet. Nat Commun. 2019;10(1):3260.

15. Arora H, Dong R, Venanzi T, Zscharschuch J, Schneider H, Helm M, Feng X, Cánovas E, Erbe A. Demonstration of a broadband photodetector based on a two-dimensional metal-organic framework. Adv Mater (Deerfield Beach Fla). 2020;32(9): e1907063.

16. Papurello RL, Lozano LA, Ramos-Fernández EV, Fernández JL, Zamaro JM. Post-synthetic modification of ZIF-8 crystals and films through UV light photoirradiation: impact on the physicochemical behavior of the MOF. ChemPhysChem. 2019;20(23):3201-9.

17. Haider G, Usman M, Chen T-P, Perumal P, Lu K-L, Chen Y-F. Electrically driven white light emission from intrinsic metal-organic framework. ACS Nano. 2016;10(9):8366-75.

18. Alvaro M, Carbonell E, Ferrer B, Llabrési Xamena FX, Garcia H. Semiconductor behavior of a metal-organic framework (MOF). Chemistry (Weinheim an der Bergstrasse Germany). 2007;13(18):5106-12.

19. Rehman S, Ullah R, Butt AM, Gohar ND. Strategies of making TiO2 and ZnO visible light active. J Hazard Mater. 2009:170(2-3):560-9.

20. Kuc A, Enyashin A, Seifert G. Metal-organic frameworks: structural, energetic, electronic, and mechanical properties. J Phys Chem B. 2007;111(28):8179-86.

21. Takagahara T. Effects of dielectric confinement and electron-hole exchange interaction on excitonic states in semiconductor quantum dots. Phys Rev B Condensed Matter. 1993;47(8):4569-84.

22. Marto J, Gouveia LF, Gonçalves L, Chiari-Andréo BG, Isaac V, Pinto P, Oliveira E, Almeida AJ, Ribeiro HM. Design of novel starch-based pickering emulsions as platforms for skin photoprotection. J Photochem Photobiol B Biol. 2016;162:56-64.

23. Sayre RM, Agin PP, LeVee GJ, Marlowe E. A comparison of in vivo and in vitro testing of sunscreening formulas. Photochem Photobiol. 1979:29(3):559-66.

24. Tyagi N, Srivastava SK, Arora S, Omar Y, ljaz ZM, Al-Ghadhban A, Deshmukh SK, Carter JE, Singh AP, Singh S. Comparative analysis of the relative potential of silver, zinc-oxide and titanium-dioxide nanoparticles against UVB-induced DNA damage for the prevention of skin carcinogenesis. Cancer Lett. 2016;383(1):53-61.

25. Gutiérrez-Hernández JM, Escalante A, Murillo-Vázquez RN, Delgado E, González FJ, Toríz G. Use of agave tequilana-lignin and zinc oxide nanoparticles for skin photoprotection. J Photochem Photobiol B Biol. 2016;163:156-61.

26. Kumar P, Nagarajan A, Uchil PD. Analysis of cell viability by the MTT assay. Cold Spring Harb Protoc. 2018. https://doi.org/10.1101/pdb.prot095505.

27. Yamada M, Mohammed Y, Prow TW. Advances and controversies in studying sunscreen delivery and toxicity. Adv Drug Deliv Rev. 2020;153:72-86.

28. Pal A, Alam S, Mittal S, Arjaria N, Shankar J, Kumar M, Singh D, Pandey AK, Ansari KM. UVB irradiation-enhanced zinc oxide nanoparticles-induced 
DNA damage and cell death in mouse skin. Mutation Res Genet Toxicol Environ Mutagenesis. 2016;807:15-24.

29. Egerton TA, Tooley IR. UV absorption and scattering properties of inorganic-based sunscreens. Int J Cosmet Sci. 2012;34(2):117-22.

30. Mao P, Smerdon MJ, Roberts SA, Wyrick JJ. Chromosomal landscape of UV damage formation and repair at single-nucleotide resolution. Proc Natl Acad Sci USA. 2016;113(32):9057-62.

31. Ablon G. Safety and effectiveness of an automated microneedling device in improving the signs of aging skin. J Clin Aesthet Dermatol. 2018;11(8):29-34.

32. Kong SZ, Li DD, Luo H, Li WJ, Huang YM, Li JC, Hu Z, Huang N, Guo MH, Chen Y, Li SD. Anti-photoaging effects of chitosan oligosaccharide in ultraviolet-irradiated hairless mouse skin. Exp Gerontol. 2018;103:27-34.

33. Fang IM, Yang $\mathrm{CM}$, Yang $\mathrm{CH}$. Chitosan oligosaccharides prevented retinal ischemia and reperfusion injury via reduced oxidative stress and inflammation in rats. Exp Eye Res. 2015;130:38-50.

34. Han S, Kang SM, Oh JH, Lee DH, Chung JH. Src kinase mediates UVinduced TRPV1 trafficking into cell membrane in $\mathrm{HaCaT}$ keratinocytes. Photodermatol Photoimmunol Photomed. 2018;34(3):214-6.

35. Li M, Lin XF, Lu J, Zhou BR, Luo D. Hesperidin ameliorates UV radiationinduced skin damage by abrogation of oxidative stress and inflammatory in HaCaT cells. J Photochem Photobiol B Biol. 2016;165:240-5.

36. Misawa E, Tanaka M, Saito M, Nabeshima K, Yao R, Yamauchi K, Abe F, Yamamoto Y, Furukawa F. Protective effects of Aloe sterols against UVBinduced photoaging in hairless mice. Photodermatol Photoimmunol Photomed. 2017;33(2):101-11.

37. Fang L, Teuchert M, Huber-Abel F, Schattauer D, Hendrich C, Dorst J, Zettlmeissel H, Wlaschek M, Scharffetter-Kochanek K, Kapfer T, Tumani H, Ludolph AC, Brettschneider J. MMP-2 and MMP-9 are elevated in spinal cord and skin in a mouse model of ALS. J Neurol Sci. 2010;294(1-2):51-6.

38. Taddese S, Jung MC, Ihling C, Heinz A, Neubert RH, Schmelzer CE. MMP-12 catalytic domain recognizes and cleaves at multiple sites in human skin collagen type I and type III. Biochem Biophys Acta. 2010;1804(4):731-9.

39. Liu Y, Chen JY, Shang HT, Liu CE, Wang Y, Niu R, Wu J, Wei H. Light microscopic, electron microscopic, and immunohistochemical comparison of Bama minipig (Sus scrofa domestica) and human skin. Comp Med. 2010;60(2):142-8.

40. Oh K-S, Bustin M, Mazur SJ, Appella E, Kraemer KH. UV-induced histone H2AX phosphorylation and DNA damage related proteins accumulate and persist in nucleotide excision repair-deficient XP-B cells. DNA Repair. 2011;10(1):5-15.

41. Weigmann HJ, Schanzer S, Patzelt A, Bahaban V, Durat F, Sterry W, Lademann J. Comparison of human and porcine skin for characterization of sunscreens. J Biomed Opt. 2009;14(2): 024027.

42. Gulson B, Wong H, Korsch M, Gomez L, Casey P, McCall M, McCulloch M, Trotter J, Stauber J, Greenoak G. Comparison of dermal absorption of zinc from different sunscreen formulations and differing UV exposure based on stable isotope tracing. Sci Total Environ. 2012;420:313-8.

43. Zhan WW, Kuang Q, Zhou JZ, Kong XJ, Xie ZX, Zheng LS. Semiconductor@metal-organic framework core-shell heterostructures: a case of ZnO@ZIF-8 nanorods with selective photoelectrochemical response. J Am Chem Soc. 2013:135(5):1926-33.

44. Heylings JR, Davies DJ, Burton R. Dermal absorption of testosterone in human and pig skin in vitro. Toxicol In Vitro. 2018:48:71-7.

45. Hunter-Sellars E, Saenz-Cavazos PA, Houghton AR, McIntyre SR, Parkin IP, Williams DR. Sol-gel synthesis of high-density zeolitic imidazolate framework monoliths via ligand assisted methods: exceptional porosity hydrophobicity, and applications in vapor adsorption. Adv Funct Mater. 2021; 31(5):2008357.

46. Zheng WJ, Ding R, Yang K, Dai Y, Yan XM, He GH. ZIF-8 nanoparticles with tunable size for enhanced $\mathrm{CO} 2$ capture of Pebax based MMMs. Sep Purif Technol. 2019;214:111-9.

47. Park KS, Ni Z, Côté AP, Choi JY, Huang R, Uribe-Romo FJ, Chae HK, O'Keeffe $M$, Yaghi OM. Exceptional chemical and thermal stability of zeolitic imidazolate frameworks. Proc Natl Acad Sci USA. 2006;103(27):10186-91.

48. Shen K, Zhang L, Chen X, Liu L, Zhang D, Han Y, Chen J, Long J, Luque R, Li $Y$, Chen B. Ordered macro-microporous metal-organic framework single crystals. Science (New York, NY). 2018;359(6372):206-10.

49. Hafizovic J, Bjorgen M, Olsbye U, Dietzel PDC, Bordiga S, Prestipino C, Lamberti C, Lillerud KP. The inconsistency in adsorption properties and powder XRD data of MOF-5 is rationalized by framework interpenetration and the presence of organic and inorganic species in the nanocavities. J Am Chem Soc. 2007;129(12):3612-20.

50. Winston EB, Lowell PJ, Vacek J, Chocholousova J, Michl J, Price JC. Dipolar molecular rotors in the metal-organic framework crystal IRMOF-2. Phys Chem Chem Phys. 2008;10(34):5188-91.

51. Eddaoudi M, Kim J, Rosi N, Vodak D, Wachter J, O'Keeffe M, Yaghi OM. Systematic design of pore size and functionality in isoreticular MOFs and their application in methane storage. Science (New York, NY). 2002;295(5554):469-72.

52. Balupillai A, Nagarajan RP, Ramasamy K, Govindasamy K, Muthusamy G. Caffeic acid prevents UVB radiation induced photocarcinogenesis through regulation of PTEN signaling in human dermal fibroblasts and mouse skin. Toxicol Appl Pharmacol. 2018;352:87-96.

53. Zhong J, Li L. Skin-derived precursors against UVB-induced apoptosis via BCl-2 and Nrf2 upregulation. Biomed Res Int. 2016;2016:6894743.

54. Petersen B, Wulf HC. Application of sunscreen - theory and reality. Photodermatol Photoimmunol Photomed. 2014;30(2-3):96-101.

55. Kim SY, Lamichhane S, Jung-Hun J, Yun J. Protective effect of octylmethoxycinnamate against UV-induced photoaging in hairless mouse via the regulation of matrix metalloproteinases. Int J Mol Sci. 2018;19(7):1836. https://doi.org/10.3390/ijms19071836.

\section{Publisher's Note}

Springer Nature remains neutral with regard to jurisdictional claims in published maps and institutional affiliations.

Ready to submit your research? Choose BMC and benefit from:

- fast, convenient online submission

- thorough peer review by experienced researchers in your field

- rapid publication on acceptance

- support for research data, including large and complex data types

- gold Open Access which fosters wider collaboration and increased citations

- maximum visibility for your research: over $100 \mathrm{M}$ website views per year

At BMC, research is always in progress.

Learn more biomedcentral.com/submissions 